\title{
Working
}

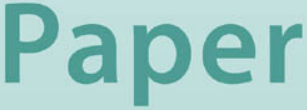


Consequences of Asset Shortages in Emerging Markets

Jiaqian Chen and Patrick Imam 


\title{
IMF Working Paper
}

Monetary and Capital Markets

\section{Consequences of Asset Shortages in Emerging Markets}

\author{
Prepared by Jiaqian Chen and Patrick Imam ${ }^{1}$
}

Authorized for distribution by Robert Rennhack

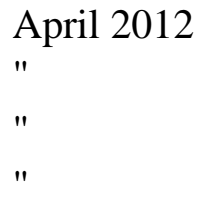

\section{This Working Paper should not be reported as representing the views of the IMF.}

The views expressed in this Working Paper are those of the authors and do not necessarily represent those of the IMF or IMF policy. Working Papers describe research in progress by the authors and are published to elicit comments and to further debate.

\section{\$ EWNFW}

We assess econometrically the impact of asset shortages on economic growth, asset bubbles, the probability of a crisis, and the current account for a group of 41 Emerging markets for 1995-2008. The econometric estimations confirm that asset shortages pose a serious danger to EMs in terms of reducing economic growth, raising the probability of a crisis, and leading to asset price bubbles. Moreover, asset shortages can also explain the current account positions of EMs. The findings suggest that the consequences of asset shortages for macroeconomic stability are significant, and must be tackled urgently. We conclude with policy implications.

JEL Classification Numbers:E22, E40, G0

Keywords: Asset Shortage, Emerging Market, Crisis, Current Account, Asset Bubble Author's E-Mail Address:j.chen@1se.ac.uk; pimam@imf.org

\footnotetext{
${ }^{1}$ We would like to thank Nataliya Ivanyk, Kangni Kpodar, Cheng Hoon Lim, Carlos Medeiros, Gian Maria Milesi-Ferretti, Ken Miyajima, Danny Quah and Robert Rennhack for useful comments. The paper also benefited from comments made at the Monetary and Capital Market seminar at the IMF, a seminar at the London School of Economics, a Conference at the Midwest Economic Association held in March 2011 in St Louis, Missouri, and a seminar at the Bank of England in August 2011. The views expressed are those of the authors and do not reflect those of the IMF.
} 
I. Introduction

II. Asset Shortages - Too Much Savings Chasing Too Few Assets ……………......................

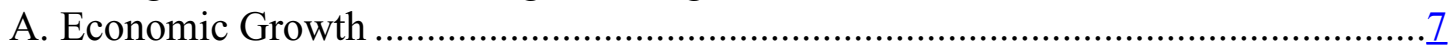

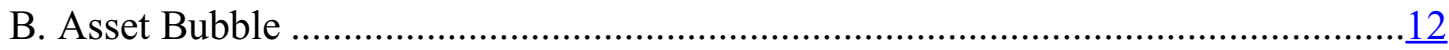

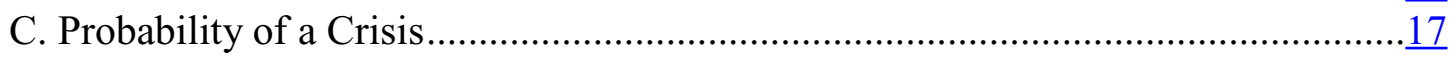

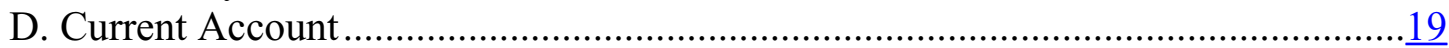

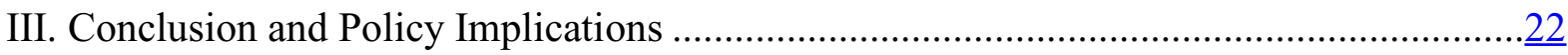

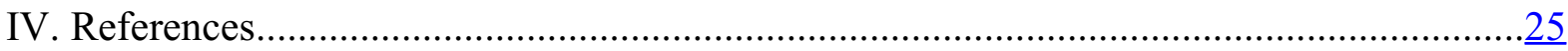

Tables

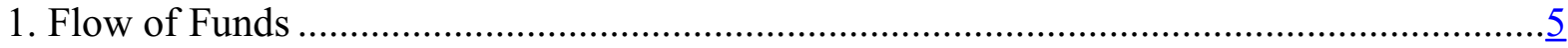

2. System-GMM Regression Results for Explaining GDP Growth ……...............................

3. Panel Unit Root Test for 1995-2008, using Im, Pesaran, and Shin (2003) .........................10

4. Panel Co-integration Test (Pedroni, 2004) Using Rats...................................................11

5. Panel Causality Test Results for 39 Countries during 1995-2008, using Rats ....................12

6. Panel Unit Root Test for 1998-2008, Using Im, Pesaran, and Shin (2003) .........................15

7. System GMM Panel Regression for Asset Bubbles, 1990-2008 ….................................16

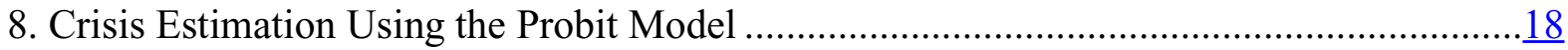

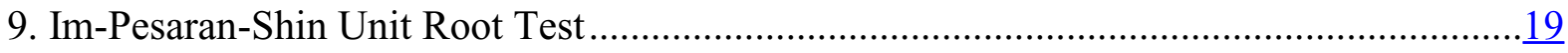

10. Estimating Changes in the Current Account Using System-GMM ..................................

Figures

1. Asset Bubbles in EMs for Equity, Government Bonds, and Housing, ..............................14

2. Reponses of the Key Variables After the Borrowing Ability Shock ...................................33

Appendixes

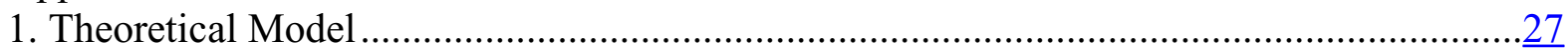

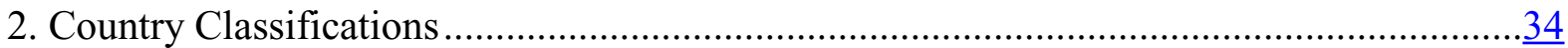

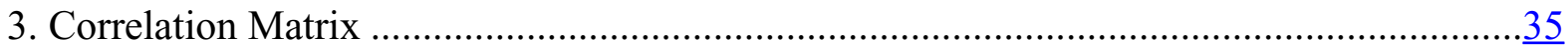

4A. Econometric Methodology - System GMM...........................................................

4B. Econometric Methodology - Panel Unit Root Test (Im et al., 2003) ................................37

4C. Econometric Methodology - Panel Cointegration Test (Pedroni, 2004)............................

4D. Econometric Methodology - Causality Tests for Cointegrated Panels ………....................39

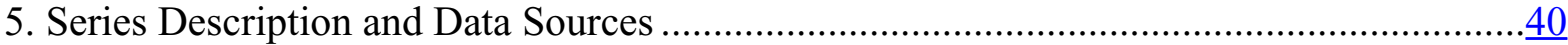




\section{INTRODUCTION}

With the start of the new millennium, a "golden decade" of macroeconomic stability and economic growth has put emerging markets (EMs) back on the map for investors. Following the 1980s debt crisis in Latin America and the 1990s Asian crisis, most EMs undertook bold reforms, encompassing orthodox fiscal policies, a predictable monetary stance, and other measures that led to strengthened balance sheets in both the public and private sectors. These economies - with the exception of those in Eastern Europe - managed to maintain this newfound economic stability through the 2008 global credit crisis.

Paradoxically, however, the growing appetite for EM financial assets (such as equity or bonds) by local and foreign investors has not been met by a commensurate increase in the supply of these assets. This is because an economy's ability to produce output is only imperfectly linked to its ability to generate financial assets. ${ }^{2}$ This explains why, since the 1990s, asset issuance as a share of GDP in EMs has not increased in parallel with GDP (see Figure 1). While EMs accounted for roughly 30 percent of global GDP in 2010 , they accounted for only about 15 percent of global financial assets.

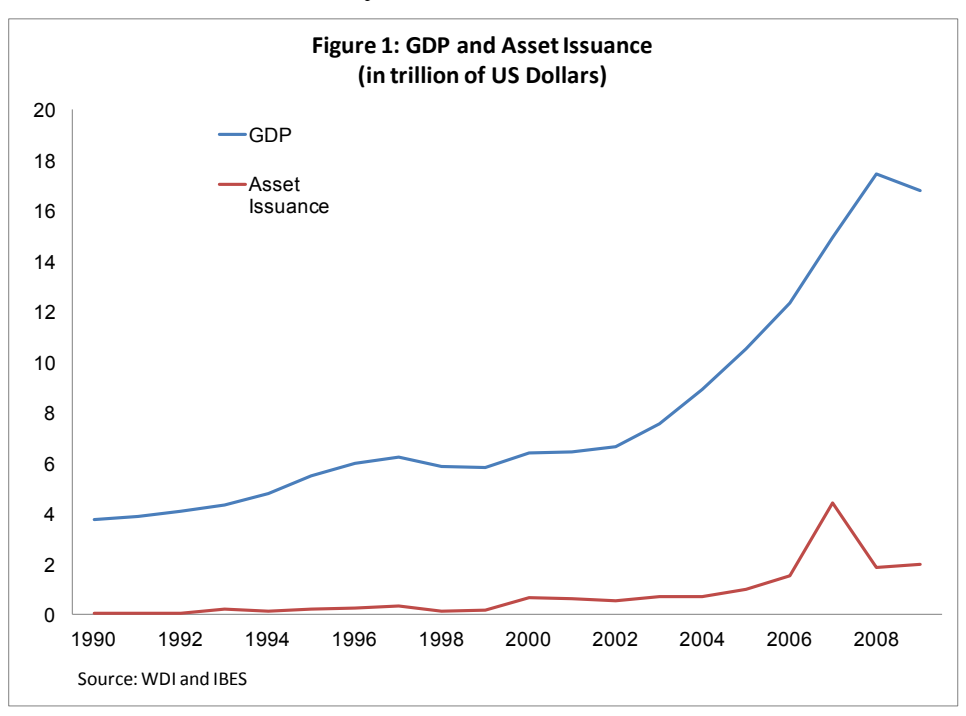

Despite high equity returns, a stable macroeconomic environment, and increasing assets under management by institutional investors, the primary market in most EMs has not taken off. Stock market capitalization - that is, the total value of the tradable shares of companies on the stock market-has largely increased due to valuation changes from price increases, not because new companies have come to the stock market. Not only are initial public offerings (IPOs) still infrequent, but most domestic fixed income markets remain underdeveloped and dominated by public debt. Outside of short-term public debt, most fixedincome products remain illiquid. Why isn't there a greater expansion in the supply of domestic financial assets in these countries? The answer is partly related to market size. Outside of the BRICs - Brazil, Russia, India, and China - corporations tend to be small, limiting the scope for equity and bond issuance, which requires a minimum scale to make it worthwhile. Most EMs do not have many large companies able to issue bonds on a scale

\footnotetext{
${ }^{2}$ While the recent literature has emphasized the lack of safe financial assets as a store of value (e.g., Caballero, Ricardo, 2006 "On the Macroeconomics of Asset Shortages" MIT mimeo), we argue that, within EMs, the issue is less one of safe assets (as a store of value), and more about there simply not being enough assets to invest in.
} 
large enough to create a vibrant stock market. In addition to size, the corporate culture also plays a part in explaining why (family) controlling shareholders are reluctant to issue shares.

Why have asset shortages - EMs producing too few financial assets relative to rising demandarisen? First, improved macroeconomic fundamentals have raised the demand for financial assets. Rising income per capita in EMs, pension reforms in Latin America, increasing commodity prices in the Middle East and Africa, and limited consumption growth in East Asia have contributed to an increasing supply of domestic savings in EMs that needs to be invested. In addition, Advanced Economies (AEs), to diversify their holdings, have increased their appetite for EM assets, reducing the supply of domestic financial assets available to EM investors.

At the same time, there is a dwindling supply of some financial assets in EMs due to orthodox fiscal policies. Although the issuance of domestic debt has recently increased, abstinence from debt has been the strategy of choice for EMs, leading to relatively lower government bond issuance compared to the past (Hausmann and Panizza, 2010). Moreover, financial frictions are curbing the supply of financial assets, with regulatory restrictions limiting the supply of financial assets. Some EMs (e.g., China) do not allow the issuance of high-yield debt or other financial assets outside of plain-vanilla types, preventing the development of a whole asset class. Following repeated crises, banking systems in Asia and Latin America have become highly regulated, forced to keep high liquidity buffers and capital ratios. While these regulations have created stable banking systems, they have constrained asset supply.

Asset shortages can lead to potential macro-economic imbalances (see Chen and Imam, 2011). The mismatch between buyers and sellers leads to investors adopting buy-and-hold strategies that dry up liquidity. In turn, fewer transactions limit price discovery in domestic capital markets (and lend themselves to market misconduct or price volatility from noise traders). Not only are there fewer investment opportunities, but the lack of domestically financial assets, if not addressed could lead to macroeconomic imbalances that threaten financial stability, including:

- Low real interest rates. With too much savings chasing too few investments, real interest rates are kept low. Low interest rates push investors to search for higher yields by moving into higher-risk assets, bringing real interest rates down further.

- Lower economic growth. If savings cannot be effectively intermediated, investment opportunities will remain on the sideline, curbing investment, and hence growth.

- Misalignment in the valuation of assets, leading to bubbles in extreme cases. In a world of imperfect capital mobility, market efficiency is impaired by mismatch of asset supply and demand, leading to misalignments in valuation relative to fundamentals.

- $\quad$ Capital flows from emerging markets to advanced economies. Classical economic theory predicts that capital should flow from rich countries to poor countries. With a limited pool of domestic assets, savers in EMs invest their savings overseas instead. 
This paper aims to econometrically test the above propositions (see Appendix 1 for a theoretical model), and to demonstrate that if the supply-demand imbalance of domestically investable financial assets is not addressed, it could potentially result in large macroeconomic imbalances that threaten financial and macroeconomic stability. The paper is structured as follows. In Section II, we estimate econometrically the factors driving asset shortages. Section IV concludes with policy implications.

\section{Asset Shortages-Too Much Savings Chasing Too Few Assets}

As developed in Chen and Imam (2011), the asset shortage (AS)-index is derived from the flow of funds accounts. The diagram below illustrates the foundation of the asset shortage index, in which household savings is being invested in either liquid or non-liquid financial assets. On the demand side, enterprises, government and households issue new loans, bonds, or equity to finance their real investment project (or consumption), ranging from a new mortgage to a new enterprise. Alternatively, they finance projects either by reducing shortterm assets or through foreign borrowing.

\section{Table 1. Flow of Funds}

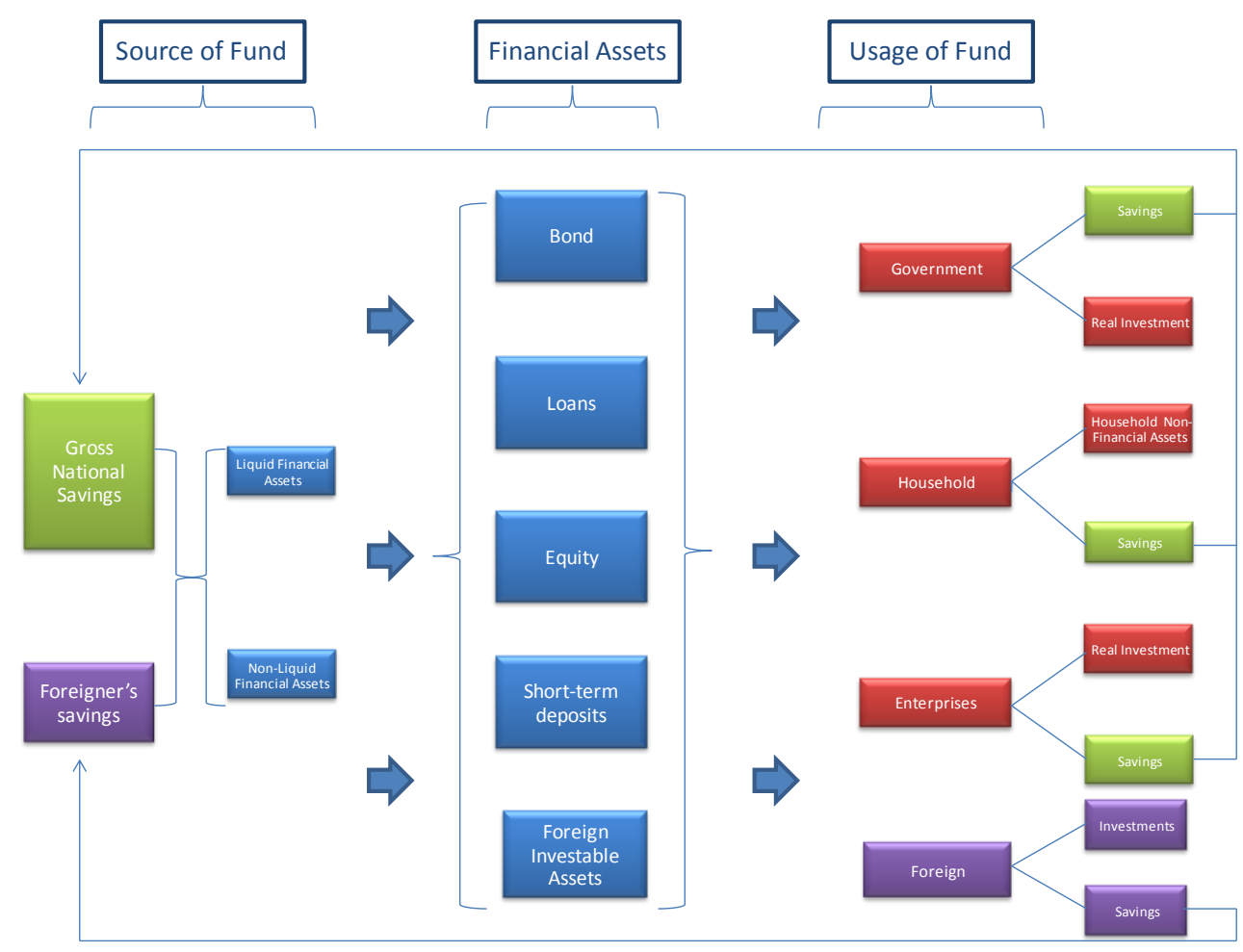

According to the system of national accounts, the national financial account comprises seven categories of investment assets:

- $\quad$ monetary gold; 
- $\quad$ currency and deposits;

- $\quad$ securities other than shares;

- loans;

- $\quad$ shares and other equity;

- $\quad$ insurance technical reserves; and

- other accounts receivable.

The AS-index captures well currency and deposits, loans, and shares and other equity. The remaining terms, for the purposes of the AS-Index, are less well captured, but are unlikely to be significant. For example, monetary gold is mainly an investment option for the central banks. Also, the level of monetary gold reserves in the central bank does not vary from year to year, so in the overall economy monetary gold has very little relevance to asset shortages. Insurance technical reserves are very small in EMs, and data limitations made it impossible to include it in the index. Other accounts receivable are in general small in EMs; limited and underdeveloped credit ratings data make it difficult for companies to assess the risk of lending. Moreover, the duration of such a transaction is very short, limiting its importance.

The AS-Index captures the difference between demand and supply for financial assets. Domestic demand for assets (latent asset demand) is proxied by gross domestic savings (i.e., all the resources available to invest), while the supply of financial assets is defined as domestic issuance of bonds, loans, and equity, as well as the net purchase of foreign assets and domestic assets by foreign investors. In addition, the change in short-term deposits also is considered to be adding to the supply of financial asset, because it reflects the temporary parking of funds, which could be motivated by a willingness to hold liquid assets as a precaution.

To estimate our asset shortages (AS) index, we use the following formula:

$$
A S=1-\left(\frac{B+E+L+\Delta S \cdot D .+N P F A}{S}\right)
$$

where $\mathrm{S}=$ domestic national savings, $\mathrm{B}=$ bond issuance in the domestic market, $\mathrm{E}=$ equity issuance in the domestic market, $\mathrm{L}=$ loan issuance in the domestic market, and S.D.= short-term deposits. $\mathrm{NPFA}=$ net purchase of foreign financial assets by domestic residents, which reflects the position of domestic investors ' holdings of foreign assets (debt, equity, financial derivatives, other investments) minus the net position of foreign investors ' holdings of domestic assets. The NPFA varies from country to country--for instance because of different level of capital account restriction or regulation on overseas investment. It can therefore act as a binding constrain on asset shortages if foreigners are allowed to buy domestic assets, but domestic residents are restricted in their purchase of foreign assets. The sum of $B+E+L+\triangle S . D .+N P F A$ is therefore a reflection of the supply of financial assets (see Chen and Imam, 2011 for a description of the evolution of the AS-index across regions and over time).

Intuitively, for asset shortages to exist market imperfections must be present; otherwise interest rates would balance the supply and demand for assets. Either savings are not responsive to interest rates (and there is a lot of empirical evidence suggesting that savings are indeed highly 
inelastic relative to interest rates) or the supply of assets is not responsive to interest rates alone (e.g., institutional factors discourage issuance of financial assets). Also, capital markets are subject to market inefficiencies - noncompetitive markets lead to high transaction costs, information asymmetry, poor enforcement of property rights — and these problems are particularly severe in EMs, holding back the issuance of financial assets.

\section{A. Economic Growth}

It is not enough for countries to generate savings if there is a lack of assets through which savings can be intermediated (see Chen and Imam, 2011). This section will demonstrate that asset shortages - owing either to insufficient investment opportunities or to savings not being properly intermediated - can hold back economic growth. In the real world, the intermediation of savings, either via banks or capital markets, to those who have investment projects with net present values is crucial. Without this intermediation, investment would not get financed, generating suboptimal growth (see also King and Levine 1993a, 1993b).

Asset shortages, as measured by the asset shortage (AS)-index, is likely to have an asymmetric impact on growth. Countries with asset shortages are expected to have creditconstrained firms, holding back growth. On the other hand, if there is an excess supply of financial assets, the impact on growth is likely to be more ambiguous, because financing can also come from overseas if domestic savings is insufficient, as may be the case in countries such as the US and UK. To test this proposition, the AS-index is divided into two variables: (i) AS-index above zero corresponding to a country with asset shortages at a given period of time, and (ii) AS-index below zero representing asset surplus. We will also differentiate between the impact of asset shortages on short-term and on long-term growth. ${ }^{3}$

\section{Short-Run Relationship}

As many of the variables explaining asset shortages are potentially endogenous, to empirically assess the impact of asset shortages on growth, we resort to system-GMM (see Appendix 4A). As estimators are often sensitive to other conditional variables another potential concern is the potential lack of robustness (Sala-i-Martin, 1997; Levine and Renelt, 1992; and Durlauf, Johnson, and Temple, 2005). Therefore, an approach suggested by Bosworth and Collins (2003) is adopted, in which the focus is on a core set of explanatory variables that have been associated consistently with growth. We then evaluate the importance of other variables conditional on inclusion of the core set. Based on the existing literature, the following variables are therefore included as core explanatory variables: real exchange rate, inflation level, corruption, government deficit, world GDP growth, GDP per

\footnotetext{
${ }^{3}$ The country classification is provided in Appendix 2, with the correlation matrix in Appendix 3. The source of data are displayed in Appendix 5.
} 
capita, legal origin, US interest rate, total trade/GDP, and percentage of secondary school enrollment as a proxy of human capital. They are then augmented with other variables.

$\triangle$ GDP Growth Git $_{1}=\beta_{1} \Delta$ A.S. Index(truncated above 0$)_{i t}+\beta_{2} \Delta$ A.S. Index (truncated below 0$)_{i t}+$ $\beta_{3} \Delta G D P$ Growth $_{i t-1}+\beta_{4} \Delta R E R_{i t}+\beta_{5} \Delta$ Inflation $_{i t}+\beta_{6} \Delta$ Inflation $_{i t}^{2}+\beta_{7} \Delta$ Real Interest Rate Rt $_{i t}+\boldsymbol{\beta}_{8} \mathbf{X}+$ $\varepsilon_{i t}$

where $\mathbf{X}$ is a matrix containing all the additional variables not included in the core regression, and $\boldsymbol{\beta}_{8}$ is the corresponding coefficient vector. Note that the Hansen J-test and ArellanoBond tests both confirm that the set of instruments chosen for the estimation is valid, in the sense that the instruments are uncorrelated with the error terms, and they satisfy the additional restriction on the first difference.

The evidence from the econometric estimation is unambiguous: Asset shortages negatively affect growth, while an asset surplus has no discernible impact. The results suggest a negative relationship between change in the AS index (truncated above zero) and subsequent GDP growth. A 1 percentage point increase in asset shortages is associated with a slowdown in annual GDP growth of around 0.7 percentage points, consistent with our original hypothesis. This implies that, as firms become financially constrained and unable to borrow to meet the desired level of investment, and savings are not allocated where they are needed, growth slows down. The findings are robust to different specifications of the regression, as displayed in Table 2, with our premises mostly confirmed. 
Table 2. System-GMM Regression Results for Explaining GDP Growth

\begin{tabular}{|c|c|c|c|c|c|c|c|c|c|c|}
\hline \multirow[b]{2}{*}{ Independent Var. } & \multicolumn{10}{|c|}{$\Delta$ GDP Growth } \\
\hline & $(1)$ & $(2)$ & (3) & $(4)$ & (5) & $(6)$ & $(7)$ & $(8)$ & (9) & $(10)$ \\
\hline$\Delta A S$ index & $\begin{array}{l}-0.135^{\star} \\
(0.079)\end{array}$ & & & & & & & & & \\
\hline$\Delta \mathrm{AS}$ index & & $-0.695^{* *}$ & $-0.695^{\star *}$ & $-0.875^{\star *}$ & $-0.683^{* *}$ & $-0.696^{* *}$ & $-0.692^{* *}$ & $-0.670^{\star *}$ & $-0.692^{* *}$ & $-0.673^{* *}$ \\
\hline (truncated above 0 ) & & $(0.317)$ & $(0.321)$ & $(0.427)$ & $(0.316)$ & $(0.319)$ & $(0.320)$ & $(0.320)$ & $(0.319)$ & $(0.319)$ \\
\hline$\Delta \mathrm{AS}$ index & & -0.016 & -0.016 & 0.029 & -0.001 & -0.017 & -0.0211 & -0.019 & -0.018 & -0.018 \\
\hline (truncated below 0 ) & & $(0.066)$ & $(0.067)$ & $(0.090)$ & $(0.068)$ & $(0.066)$ & $(0.068)$ & $(0.066)$ & $(0.066)$ & $(0.067)$ \\
\hline$\Delta$ GDP growth (t-1) & $\begin{array}{c}-0.281^{* * *} \\
(0.037)\end{array}$ & $\begin{array}{c}-0.273^{* * *} \\
(0.040)\end{array}$ & $\begin{array}{c}-0.273^{* * *} \\
(0.041)\end{array}$ & $\begin{array}{c}-0.284^{* * *} \\
(0.045)\end{array}$ & $\begin{array}{c}-0.294^{* * *} \\
(0.042)\end{array}$ & $\begin{array}{c}-0.275^{\star * *} \\
(0.041)\end{array}$ & $\begin{array}{l}-0.276^{* * *} \\
(0.0392)\end{array}$ & $\begin{array}{c}-0.282^{* * *} \\
(0.041)\end{array}$ & $\begin{array}{c}-0.277^{* * *} \\
(0.041)\end{array}$ & $\begin{array}{c}-0.284^{* * *} \\
(0.041)\end{array}$ \\
\hline$\Delta$ Real exchange rate & $0.001^{* * *}$ & $0.001^{* \star *}$ & $0.001^{* *}$ & $0.001^{* * *}$ & $0.001^{* * *}$ & $0.001^{* \star *}$ & $0.001^{* * *}$ & $0.001^{* * *}$ & $0.001^{* * *}$ & $0.001^{* * *}$ \\
\hline & $(0.0003)$ & $(0.0003)$ & $(0.0004)$ & $(0.0004)$ & $(0.0003)$ & $(0.0004)$ & $(0.0003)$ & $(0.0003)$ & $(0.0003)$ & $(0.0003)$ \\
\hline$\Delta$ Inflation & $-0.394^{* * *}$ & $-0.386^{* * *}$ & $-0.386^{* * *}$ & $-0.506^{* * *}$ & $-0.408^{* * *}$ & $-0.388^{* * *}$ & $-0.389^{* * *}$ & $-0.392^{* \star *}$ & $-0.390^{\star * *}$ & $-0.394^{* * *}$ \\
\hline & $(0.106)$ & $(0.106)$ & $(0.108)$ & $(0.123)$ & $(0.108)$ & $(0.108)$ & $(0.107)$ & $(0.108)$ & $(0.107)$ & $(0.107)$ \\
\hline$\Delta$ Inflation squared & $0.002^{\star *}$ & $0.002^{* *}$ & $0.002^{* *}$ & $0.003^{* * *}$ & $0.002^{\star *}$ & $0.002^{* \star}$ & $0.002^{* *}$ & $0.002^{* *}$ & $0.002^{* *}$ & $0.002^{* *}$ \\
\hline & $(0.001)$ & $(0.001)$ & $(0.001)$ & $(0.001)$ & $(0.001)$ & $(0.001)$ & $(0.001)$ & $(0.001)$ & $(0.001)$ & $(0.001)$ \\
\hline$\Delta$ Real interest rate & $\begin{array}{c}-0.184^{\star * *} \\
(0.035)\end{array}$ & $\begin{array}{c}-0.182^{* * *} \\
(0.034)\end{array}$ & $\begin{array}{l}-0.182^{* * *} \\
(0.034)\end{array}$ & $\begin{array}{l}-0.178^{* * *} \\
(0.039)\end{array}$ & $\begin{array}{l}-0.159^{* * *} \\
(0.034)\end{array}$ & $\begin{array}{l}-0.181^{* * *} \\
(0.034)\end{array}$ & $\begin{array}{l}-0.181^{* * *} \\
(0.034)\end{array}$ & $\begin{array}{l}-0.174^{* * *} \\
(0.034)\end{array}$ & $\begin{array}{l}-0.180^{* * *} \\
(0.034)\end{array}$ & $\begin{array}{c}-0.174^{\star * *} \\
(0.034)\end{array}$ \\
\hline$\Delta$ Corruption & & & $\begin{array}{c}-0.00400 \\
(0.426)\end{array}$ & & & & & & & \\
\hline Government deficit & & & & $\begin{array}{c}0.015 \\
(0.019)\end{array}$ & & & & & & \\
\hline World GDP growth & & & & & $\begin{array}{l}5.840^{* * *} \\
(1.883)\end{array}$ & & & & & \\
\hline GDP per capita & & & & & & $\begin{array}{l}0.000009 \\
(0.00001)\end{array}$ & & & & \\
\hline Common law & & & & & & & $\begin{array}{l}0.262^{* *} \\
(0.115)\end{array}$ & & & \\
\hline Secondary edu. (\%) & & & & & & & & $\begin{array}{l}0.005^{*} \\
(0.003)\end{array}$ & & \\
\hline US interest rate $(\mathrm{t}-1)$ & & & & & & & & & $\begin{array}{c}0.028 \\
(0.033)\end{array}$ & \\
\hline Total trade/GDP (t-1) & & & & & & & & & & $\begin{array}{l}0.003^{* *} \\
(0.001)\end{array}$ \\
\hline $\begin{array}{l}\text { Arellano-Bond test for } \\
A R(2) \text { in first diff }\end{array}$ & 0.388 & 0.401 & 0.398 & 0.396 & 0.383 & 0.396 & 0.393 & 0.368 & 0.360 & 0.367 \\
\hline $\begin{array}{l}\text { Hansen test of overide } \\
\text { restrictions }\end{array}$ & 1.000 & 1.000 & 1.000 & 1.000 & 1.000 & 1.000 & 1.000 & 1.000 & 1.000 & 1.000 \\
\hline
\end{tabular}




\section{Long-run Relationship}

This subsection examines the long-run nature of the relationship between asset shortages and economic growth. Thus far, we have looked at their short-run relationship, ignoring both whether a long-run relationship exists and causality. We first use a panel unit root (Im, Pesaran, and Shin, 2003, see Appendix 4B) and panel co-integration tests (Pedroni 1999, 2004, see Appendix 4C) to determine the long-run relationship. These allow for heterogeneity in coefficients and different dynamics across units. This enables us to determine the long-run structure of the asset-shortage and growth relationship, avoiding the problems of low power that occur in traditional (time-series) co-integration testing owing to the small samples. We also test the direction of the causality by employing a panel cointegration causality test (Canning and Pedroni 2008, see Appendix 4D).

Before embarking on co-integration techniques, we need to test for non-stationarity against the alternative that the variables are trend stationary, where we allow different intercepts and time trends for each country. We adopt the Im et al. (2003) approach, which allows each panel member to have a different autoregressive parameter and short-run dynamics under the alternative hypothesis of trend stationarity. The variables - GDP growth and the AS indexare tested both in levels and in first difference. We cannot reject the null hypothesis (i.e., unit root) at levels; however, the null hypothesis is rejected at the 1 percent significance level when differences are tested. In what follows, we therefore proceed on the assumption that all variables are $\mathrm{I}(1)$ and all difference variables are $\mathrm{I}(0)$ (Table 3$)$.

Table 3. Panel Unit Root Test for 1995-2008, using Im, Pesaran, Shin (2003).

\begin{tabular}{lcc}
\hline & \multicolumn{2}{c}{ Test Statistic } \\
\cline { 2 - 3 } GDP growth & \multicolumn{1}{c}{ Levels } & Differences \\
AS index & -1.565 & $-2.073^{* * *}$ \\
\hline *** Significant at 1 percent. & -1.603 & $-1.961^{* * *}$ \\
\hline
\end{tabular}

As the order of stationarity has been confirmed, we next turn to the question of possible cointegration between asset shortage and GDP growth. Given the possibility of reverse causality between the two variables, the panel co-integration technique of Pedroni (1999, 2004 ) is adopted. It is robust to causality in both directions and allows for both heterogeneous co-integrating vectors and short-run dynamics across countries. More formally, we test the following specification:

$$
\text { GDPgrowth }_{i t}=a_{i}+b_{t}+\beta_{i} \text { A.S.Index } \text { It }_{i t}+e_{i t}
$$

where each country has its own unique relationship between GDP growth and the AS index. The variable $e_{i t}$ represents a stationary error term. Furthermore, we allow for the slope of the co-integration relationship to differ from unity across countries. The common yearly dummy 
$b_{t}$ captures any factors that affect all countries at a given time. ${ }^{4}$ The findings in Table 4 confirm that, for all countries, we can reject the null hypothesis of no co-integration. Consequently, in what follows, we can assume co-integration between the AS index and GDP growth.

\section{Table 4. Panel Co-integration Test (Pedroni, 2004) Using Rats}

$* * * * * * * * * * * * * * * * * * * * * * * * * * * * * * * * * * * * * * * * * * * *$

$\begin{array}{lll}\text { panel v-stat } & = & 0.92779 \\ \text { panel rho-stat }= & -4.40936^{* * *} \\ \text { panel pp-stat }= & -8.66264^{* * *} \\ \text { panel adf-stat }= & -7.86769^{* * *} \\ \text { group rho-stat }= & -1.20192 \\ \text { group pp-stat }= & -9.32220^{* * *} \\ \text { group adf-stat }= & -7.87350^{* * *} \\ \mathrm{~N}=39, \mathrm{~T} \text { periods }= & 14\end{array}$

All reported values are distributed $N(0,1)$ under null of unit root or no co-integration Panel stats are weighted by long-run variances.

$* * * * * * * * * * * * * * * * * * * * * * * * * * * * * * * * * * * * * * * * * * * *$

Having established the existence of a long-run relationship, we tackle the issue of causality. The causality tests can be implemented on a country-by-country basis (Table 5). The countries have been grouped by region. Column 2 reports the point estimate for $\lambda_{2 i}$, column 3 reports the associated t-test for the null hypothesis that $\lambda_{2 i}=0$ and column 4 reports the corresponding $\mathrm{p}$ value for the test result from column 3. Columns 5 to 7 report the analogous results for $\lambda_{1 i}$, and the last column reports the estimate for the 'sign' ratio $-\lambda_{2 i} / \lambda_{1 i}$.

The results for most countries imply that causality runs from asset shortages to economic growth, with the impact being negative. Growth on the other hand does not have a causal impact on asset shortages in most countries. In practice, the reliability of the various point estimates and associated tests for any one country is likely to be less reliable due to the short sample period. Consequently, the focus is on the results reported in the panel data. The panel tests for the direction of long-run causality and the sign of the long-run causal effect are reported in the last two rows of Table 5. They support the view of a negative long-run causality from asset shortage to economic growth, and reject the null hypothesis of a longrun causality from economic growth to asset shortage. These results confirm the initial hypothesis that if savings cannot be intermediated, growth will suffer. Deeper financial markets, by allowing savings to be channeled to a variety of investments, ultimately stimulate growth.

\footnotetext{
${ }^{4}$ Following Pedroni (2004), we use the residual of the above regression to construct the group mean ADF test for the null hypothesis of no co-integration. The lag length for the ADF-based tests is allowed to vary across different cross-sections, and the optimal lag is chosen by the step-down procedure beginning with a maximum of five lags. The test has a normal distribution under the null hypothesis of no co-integrations.
} 
Table 5. Panel Causality Test Results for 39 Countries during 1995-2008, using Rats

\begin{tabular}{|c|c|c|c|c|c|c|c|}
\hline \multirow[b]{2}{*}{ Country } & \multicolumn{3}{|c|}{$\lambda_{2}:$ GDP Growth it $\rightarrow$ A.S.it } & \multicolumn{3}{|c|}{$\lambda_{2}: A . S_{\cdot i t} \rightarrow$ GDP Growth $i t$} & \multirow{2}{*}{$\begin{array}{c}-\lambda_{2} / \lambda_{1} \\
\text { Estimate }\end{array}$} \\
\hline & Estimate & Test & $P$ value & Estimate & Test & $P$ value & \\
\hline \multicolumn{8}{|l|}{ Latin America } \\
\hline$\overline{\text { Argentina }}$ & 0.25 & 1.33 & $(0.18)$ & 0.53 & 0.55 & $(0.58)$ & -0.47 \\
\hline Brazil & 3.15 & 1.44 & $(0.15)$ & -12.05 & -1.69 & $(0.09)$ & 0.26 \\
\hline $\begin{array}{l}\text { Chile } \\
\text { Colombia } \\
\text { Mexico } \\
\text { Panama } \\
\text { Peru } \\
\text { Venezuela Rep. }\end{array}$ & $\begin{array}{c}-0.01 \\
0.13 \\
0.12 \\
0.61 \\
-0.24 \\
-0.01\end{array}$ & $\begin{array}{l}-0.03 \\
0.92 \\
0.66 \\
0.97 \\
-0.85 \\
-0.11\end{array}$ & $\begin{array}{l}(0.98) \\
(0.36) \\
(0.51) \\
(0.33) \\
(0.40) \\
(0.91)\end{array}$ & $\begin{array}{l}-1.66 \\
-3.17 \\
-1.77 \\
-0.47 \\
-0.40 \\
-2.54\end{array}$ & $\begin{array}{l}-2.88 \\
-2.39 \\
-1.05 \\
-1.80 \\
-3.14 \\
-0.93\end{array}$ & $\begin{array}{l}(0.00) \\
(0.02) \\
(0.29) \\
(0.07) \\
(0.00) \\
(0.35)\end{array}$ & $\begin{array}{r}-0.01 \\
0.04 \\
0.07 \\
1.30 \\
0.60 \\
-0.01\end{array}$ \\
\hline \multicolumn{8}{|l|}{ East Asia } \\
\hline$\overline{\text { China PR }}$ & 0.44 & 2.13 & $(0.03)$ & -1.47 & -2.72 & $(0.01)$ & 0.30 \\
\hline China Hong Kong & 0.34 & 0.12 & $(0.90)$ & -1.79 & -1.38 & $(0.17)$ & 0.19 \\
\hline India & 0.04 & 0.30 & $(0.77)$ & -0.93 & -2.67 & $(0.01)$ & 0.05 \\
\hline Indonesia & 0.01 & 0.78 & $(0.44)$ & -0.57 & -6.07 & $(0.00)$ & 0.01 \\
\hline Korea & 0.73 & 2.70 & $(0.01)$ & -2.61 & -1.95 & $(0.05)$ & 0.28 \\
\hline Malaysia & -1.83 & -2.12 & $(0.03)$ & -0.90 & -0.52 & $(0.60)$ & -2.03 \\
\hline Philippines & -0.32 & -0.23 & $(0.82)$ & -0.72 & -0.40 & $(0.69)$ & -0.44 \\
\hline Thailand & 0.03 & 0.87 & $(0.38)$ & -0.75 & -3.12 & $(0.00)$ & 0.05 \\
\hline Vietnam & -0.30 & -0.96 & $(0.34)$ & -1.24 & -1.07 & $(0.28)$ & -0.24 \\
\hline \multicolumn{8}{|l|}{ Mid. East } \\
\hline Bahrain & 2.03 & 0.29 & $(0.77)$ & -0.18 & -0.16 & $(0.87)$ & 11.04 \\
\hline Egypt & -0.01 & -0.02 & $(0.99)$ & -0.74 & -0.41 & $(0.68)$ & -0.01 \\
\hline Israel & 0.19 & 3.31 & $(0.00)$ & -1.18 & -1.24 & $(0.22)$ & 0.16 \\
\hline Kazakhstan & 0.01 & 0.08 & $(0.94)$ & -0.85 & -1.83 & $(0.07)$ & 0.01 \\
\hline Kuwait & -0.08 & -1.25 & $(0.21)$ & -0.82 & -0.90 & $(0.37)$ & -0.08 \\
\hline Morocco & -0.51 & -0.98 & $(0.32)$ & -0.83 & -0.68 & $(0.49)$ & -0.62 \\
\hline Pakistan & 0.13 & 1.94 & $(0.05)$ & -0.56 & -0.71 & $(0.48)$ & 0.23 \\
\hline Saudi Arabia & -0.07 & -0.25 & $(0.80)$ & -1.16 & -0.84 & $(0.40)$ & -0.06 \\
\hline South Africa & -3.38 & -0.86 & $(0.39)$ & -0.45 & -0.41 & $(0.68)$ & -7.57 \\
\hline Turkey & -0.09 & -3.49 & $(0.00)$ & -2.33 & -2.66 & $(0.01)$ & -0.04 \\
\hline \multicolumn{8}{|l|}{ Eastern Europe } \\
\hline Bulgaria & 1.31 & 2.33 & $(0.02)$ & 0.44 & 0.68 & $(0.50)$ & -3.00 \\
\hline Croatia & 0.23 & 0.62 & $(0.54)$ & -0.53 & -1.16 & $(0.25)$ & 0.43 \\
\hline Czech Rep. & -0.28 & -0.26 & $(0.79)$ & -1.22 & -0.66 & $(0.51)$ & -0.23 \\
\hline Hungary & -0.14 & -0.18 & $(0.86)$ & -1.48 & -0.99 & $(0.32)$ & -0.10 \\
\hline Latvia & -0.27 & -0.43 & $(0.67)$ & -2.40 & -0.74 & $(0.46)$ & -0.11 \\
\hline Lithuania & -0.08 & -0.18 & $(0.86)$ & -1.90 & -0.69 & $(0.49)$ & -0.04 \\
\hline Poland & 0.17 & 0.47 & $(0.64)$ & -0.90 & -1.18 & $(0.24)$ & 0.18 \\
\hline Romania & 0.06 & 0.41 & $(0.69)$ & -0.60 & -1.93 & $(0.05)$ & 0.10 \\
\hline Russia & -0.02 & -1.06 & $(0.29)$ & -0.66 & -8.67 & $(0.00)$ & -0.03 \\
\hline Slovak Rep. & 0.54 & 0.64 & $(0.53)$ & -2.32 & -3.07 & $(0.00)$ & 0.23 \\
\hline Slovenia & 0.01 & 0.01 & $(0.99)$ & -2.60 & -2.66 & $(0.01)$ & 0.00 \\
\hline Ukraine & 0.04 & 0.81 & $(0.42)$ & -0.62 & -1.71 & $(0.09)$ & 0.07 \\
\hline $\begin{array}{l}\text { Group mean } \\
\text { Lambda_Pearson }\end{array}$ & 0.08 & $\begin{array}{c}0.25 \\
106.93\end{array}$ & $\begin{array}{l}(0.60) \\
(0.02)\end{array}$ & -1.45 & $\begin{array}{c}-1.69 \\
287.95\end{array}$ & $\begin{array}{l}(0.05) \\
(0.00)\end{array}$ & $\begin{array}{l}0.00 \\
(0.05)\end{array}$ \\
\hline
\end{tabular}

\section{B. Asset Bubbles}

We argued in Chen and Imam (2011) that asset bubbles have become ever more frequent. Empirically, however, it is difficult to test for asset bubbles ex ante. Theoretically, rising asset bubbles tend to be (i) caused by macroeconomic factors (e.g., overheating), or (ii) are driven by speculation. It is crucial to identify which one of these two reasons may lead to a 
crisis in EMs. Economists typically identify the two forces by investigating the extent to which macroeconomic variables explain asset prices, and the variation that cannot be explained is assumed to be driven by speculative demand. Owing to market imperfections, and given rising evidence from behavioral finance that economic agents are driven by psychology (overconfidence, heuristic bias, framing, etc.) as much as by fundamentals, the assumption that asset prices reflect market fundamentals does not always hold. Therefore, asset prices can deviate from market fundamentals. One factor that to our knowledge has not been explicitly tested is the impact of asset shortages on bubbles. As Tirole (1985) argued, it is always difficult to identify the right set of variables as proxy for market fundamentals. What is the correct set of variables to use as market fundamentals?

Our analysis begins by constructing an index to proxy asset overvaluation. The methodology is based on the bubble-o-meter used in the GFSR (2010). The asset bubble is a weighted average of three z-scores corresponding to three major assets for each country. ${ }^{5}$ The three asset classes used to construct the asset bubble index are (i) equity, measured by a forwardlooking (shorter horizon) 12-month price-to-earnings ratio; (ii) housing, proxied by a priceto-rent ratio by rescaling residential house prices by rental rates; and (iii) local sovereign bonds, estimated by local sovereign yield. The z-score represents the deviation of the latest observation from the model prediction and is demeaned and normalized by its standard deviation. This provides a natural standardization for the three asset classes.

There is some evidence in our sample of countries that prices have increased gradually over time for all assets, though with variation across asset classes (Figure 2). The housing market in EMs followed a similar pattern to that in AEs, with a steady rise in the deviation of house prices from fundamentals, even after the 2008 crisis. The equity market in EMs also has deviated above its equilibrium in recent years, though with the volatility often associated with a crisis. The z-scores for domestic sovereign bonds show a mean reversion process, meaning that a below-model predicted yield is always followed by a higher-than-model predicted valuation.

The intent is to estimate whether asset shortages are a key driver of asset bubbles in EMs. We want to test whether the AS index has a significant impact on the deviation of asset prices as predicted by its market fundamentals. Besides the AS index, we use a set of macro variables that are deemed important in determining asset prices: domestic GDP growth, inflation, real interest rate, government fiscal balance, real exchange rate, legal origin, and dependency ratio. Moreover, variables that explain the international macroeconomic environment, namely US interest rates and world GDP growth, are also taken into account. The core regression has the following form:

$\Delta$ Bubble Index $_{i t}=\beta_{1}$ A.S. Index $_{i t}+\beta_{2}$ GDP growth $_{i t}+\beta_{3}$ Inflation $_{i t}+\beta_{4}$ Real Interest Rate $_{i t}+\boldsymbol{\beta}_{5} \mathbf{X}+$ $\varepsilon_{i t}$

\footnotetext{
${ }^{5}$ Other assets should ideally also be included, for example, corporate bond yield; but because of data limitations in emerging economies, they are not considered in this paper.
} 
Figure 2. Asset Bubbles in EMs for Equity, Government Bonds, and Housing 1990-2008

Z-Scores as measure of Asset Valuations

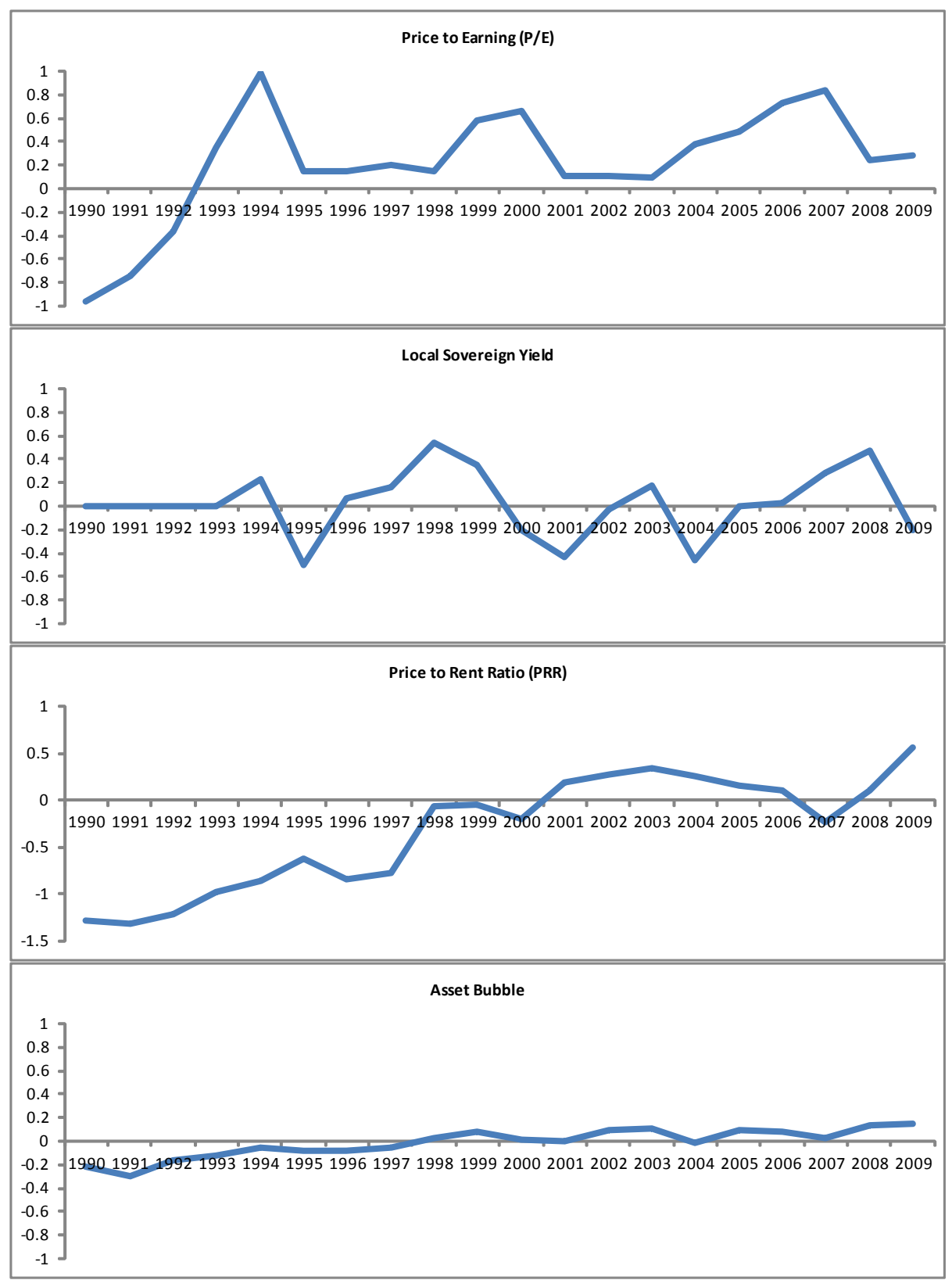

Source: IBES; Haver Analytics; Global Property Index and Authers calculations

To deal both with the possibility of reverse causality and omitted variable bias, system-GMM is again employed. Note that we lead all variables by one year, as we assume that asset prices are priced using expectations; hence they are not affected by contemporaneous variables, but by expected future ones. Before deciding whether to use level effects or first difference, we test for unit roots, with evidence of first difference, but not level effects (Table 6). We therefore use first differences. 
Table 6. Panel Unit Root Test for 1998-2008, Using Im, Pesaran, Shin (2003)

\begin{tabular}{lcc}
\hline & \multicolumn{2}{c}{ Test Statistic } \\
\cline { 2 - 3 } & Levels & Differences \\
\hline Asset Bubble Index & -1.268 & $-2.020^{* * *}$ \\
\hline
\end{tabular}

*** Significant at 1 . Null hypothesis: there is a unit root.

The results provide evidence of a strong positive link between asset shortages and asset bubbles (Table 7). Asset bubbles increase when asset shortages worsen. Columns 1-7 show that the coefficients are positive and are statistically significant at the 5 percent level. The results imply that asset prices will deviate from fundamentals if there is excess demand expected in the next period. These results do not change with the introduction of more dependent variables, suggesting a robust relationship between asset shortage and asset price bubbles.

Most fundamental factors - GDP growth, interest rates, fiscal balance, real effective exchange rate (REER) and legal origin - as expected, do not have a significant impact on the asset bubble index. This confirms that non-fundamental factors, such as psychology and market imperfections, matter more in explaining bubbles. Only future inflation has a positive and statistically significant impact on the asset bubble index. This could reflect the fact that increasing inflation, a measure associated with rising macroeconomic instability, encourages economic actors to hedge themselves by buying assets such as equity and housing, which are either natural hedges or which have some intrinsic value. 
Table 7. System GMM Panel Regression for Asset Bubbles, 1990-2008

\begin{tabular}{|c|c|c|c|c|c|c|c|c|c|c|c|c|c|c|}
\hline & \multicolumn{14}{|c|}{$\Delta$ Asset Bubble Index } \\
\hline Independent var. & (1) & (2) & (3) & (4) & (5) & (6) & (7) & (8) & (9) & $(10)$ & $(11)$ & $(12)$ & (13) & (14) \\
\hline Asset shortage index & $\begin{array}{l}0.032^{* *} \\
(0.013)\end{array}$ & $\begin{array}{l}0.031^{* *} \\
(0.013)\end{array}$ & $\begin{array}{l}0.031^{\text {** }} \\
(0.013)\end{array}$ & $\begin{array}{l}0.033^{* *} \\
(0.013)\end{array}$ & $\begin{array}{l}0.031^{* *} \\
(0.013)\end{array}$ & $\begin{array}{l}0.031^{* *} \\
(0.014)\end{array}$ & $\begin{array}{l}0.032^{\star *} \\
(0.013)\end{array}$ & $\begin{array}{l}0.031^{* *} \\
(0.013)\end{array}$ & $\begin{array}{l}0.032^{\star *} \\
(0.014)\end{array}$ & $\begin{array}{l}0.031^{* *} \\
(0.014)\end{array}$ & $\begin{array}{l}0.030^{* *} \\
(0.014)\end{array}$ & $\begin{array}{l}0.030^{* *} \\
(0.013)\end{array}$ & $\begin{array}{l}0.0285^{\star *} \\
(0.0130)\end{array}$ & $\begin{array}{l}0.032^{\star *} \\
(0.013)\end{array}$ \\
\hline GDP growth & $\begin{array}{l}-0.335 \\
(0.250)\end{array}$ & $\begin{array}{l}-0.331 \\
(0.250)\end{array}$ & $\begin{array}{l}-0.333 \\
(0.251)\end{array}$ & $\begin{array}{l}-0.309 \\
(0.253)\end{array}$ & $\begin{array}{l}-0.542 \\
(0.341)\end{array}$ & $\begin{array}{l}-0.449 \\
(0.330)\end{array}$ & $\begin{array}{l}-0.395 \\
(0.340)\end{array}$ & $\begin{array}{l}-0.504 \\
(0.339)\end{array}$ & $\begin{array}{l}-0.825^{\star \star} \\
(0.411)\end{array}$ & $\begin{array}{l}-1.005^{\star *} \\
(0.456)\end{array}$ & $\begin{array}{l}-0.853^{\star \star} \\
(0.391)\end{array}$ & $\begin{array}{l}-0.704^{*} \\
(0.393)\end{array}$ & $\begin{array}{l}-0.783^{\star} \\
(0.412)\end{array}$ & $\begin{array}{c}-0.797^{\star *} \\
(0.365)\end{array}$ \\
\hline Inflation & $\begin{array}{l}0.010^{* *} \\
(0.004)\end{array}$ & $\begin{array}{l}0.009^{* *} \\
(0.004)\end{array}$ & $\begin{array}{l}0.010^{* *} \\
(0.004)\end{array}$ & $\begin{array}{l}0.011^{* *} \\
(0.005)\end{array}$ & $\begin{array}{l}0.006 \\
(0.004)\end{array}$ & $\begin{array}{l}0.009^{* *} \\
(0.004)\end{array}$ & $\begin{array}{l}0.009^{\star *} \\
(0.00381)\end{array}$ & $\begin{array}{l}0.008^{* *} \\
(0.004)\end{array}$ & $\begin{array}{l}0.007^{\star *} \\
(0.004)\end{array}$ & $\begin{array}{l}0.006^{*} \\
(0.003)\end{array}$ & $\begin{array}{l}0.008^{* *} \\
(0.004)\end{array}$ & $\begin{array}{l}0.005 \\
(0.003)\end{array}$ & $\begin{array}{l}0.00603^{*} \\
(0.00341)\end{array}$ & $\begin{array}{c}0.002 \\
(0.004)\end{array}$ \\
\hline Real interest rate & $\begin{array}{l}-0.008 \\
(0.057)\end{array}$ & $\begin{array}{l}-0.025 \\
(0.056)\end{array}$ & $\begin{array}{l}-0.014 \\
(0.080)\end{array}$ & $\begin{array}{l}0.016 \\
(0.069)\end{array}$ & $\begin{array}{l}-0.090 \\
(0.065)\end{array}$ & $\begin{array}{l}-0.043 \\
(0.061)\end{array}$ & $\begin{array}{l}-0.011 \\
(0.055)\end{array}$ & $\begin{array}{l}-0.055 \\
(0.059)\end{array}$ & $\begin{array}{l}-0.127^{* *} \\
(0.058)\end{array}$ & $\begin{array}{l}-0.169^{\star *} \\
(0.077)\end{array}$ & $\begin{array}{l}-0.152^{\star *} \\
(0.062)\end{array}$ & $\begin{array}{l}-0.091^{*} \\
(0.051)\end{array}$ & $\begin{array}{l}-0.112^{*} \\
(0.0602)\end{array}$ & $\begin{array}{l}-0.060^{*} \\
(0.059)\end{array}$ \\
\hline Govt. fiscal balance & & $\begin{array}{c}-0.001 \\
(0.002)\end{array}$ & & & & & & & & & & & & \\
\hline Real exchange rate & & & $\begin{array}{c}0.001 \\
(0.005)\end{array}$ & & & & & & & & & & & \\
\hline Legal origin: UK & & & & $\begin{array}{l}-0.012 \\
(0.014)\end{array}$ & & & & & & & & & & \\
\hline Dependent ratio & & & & & $\begin{array}{l}0.240^{*} \\
(0.144)\end{array}$ & & & & & & & & & \\
\hline US interest rate & & & & & & $\begin{array}{c}0.003 \\
(0.005)\end{array}$ & & & & & & & & \\
\hline World GDP growth & & & & & & & $\begin{array}{c}0.073 \\
(0.198)\end{array}$ & & & & & & & \\
\hline Inst. regulation (t-1) & & & & & & & & $\begin{array}{c}0.023 \\
(0.020)\end{array}$ & & & & & & \\
\hline Financial freedom (t-1) & & & & & & & & & $\begin{array}{l}0.0009^{* *} \\
(0.0004)\end{array}$ & & & & & \\
\hline Business freedom (t-1) & & & & & & & & & & $\begin{array}{l}0.001^{* * *} \\
(0.0003)\end{array}$ & & & & \\
\hline Property rights (t-1) & & & & & & & & & & & $\begin{array}{l}0.001^{* * *} \\
(0.0003)\end{array}$ & & & \\
\hline $\begin{array}{l}\text { Government stability (t- } \\
\text { 1) }\end{array}$ & & & & & & & & & & & & & & \\
\hline Law and order (t-1) & & & & & & & & & & & & $(0.002)$ & $\begin{array}{l}0.0124^{* *} \\
(0.00568)\end{array}$ & \\
\hline Log commodity prices & & & & & & & & & & & & & & $\begin{array}{l}0.0006^{* *} \\
(0.0002)\end{array}$ \\
\hline $\begin{array}{l}\text { Arellano-Bond test for } \\
A R(2) \text { in difference }\end{array}$ & 0.108 & 0.108 & 0.110 & 0.108 & 0.108 & 0.106 & 0.107 & 0.109 & 0.116 & 0.120 & 0.121 & 0.107 & 0.108 & 0.108 \\
\hline $\begin{array}{l}\text { Hansen test overide } \\
\text { Rest. }\end{array}$ & 1.000 & 1.000 & 1.000 & 1.000 & 1.000 & 1.000 & 1.000 & 1.000 & 1.000 & 1.000 & 1.000 & 1.000 & 1.000 & 1.000 \\
\hline
\end{tabular}

Robust standard errors in parentheses

${ }^{* * *} p<0.01,{ }^{* *} p<0.05,{ }^{*} p<0.1$ 


\section{Probability of a Crisis}

Asset shortages are more likely to increase the probability of a crisis, because too much money chasing too few financial assets leads to bubbles that if excessive can end in a crisis. Rising prices tend to create euphoria and will attract the attention of investors. Herd behavior in turn reinforces pricing bubbles, which eventually burst.

A probit estimation is used to study the effect of asset shortages on the probability of crisis together with an additional set of macroeconomic variables. The dependent variable (Crisis) is a binary dummy variable that takes the value of 1 in the year crisis occurs and 0 otherwise. The regression results are presented in Table 8. A set of key variables identified in the literature as major causes of crisis, including the AS index, were selected for the econometric estimation: the log of GDP, real interest rate, a country's credit rating, government deficit, real exchange rate, inflation, and log of GDP per capita. The analysis tests the effect of legal origin, US interest rates, external debt, government debt, government revenue, and foreign asset liability and assets in separate regressions. Our probit regression follows:

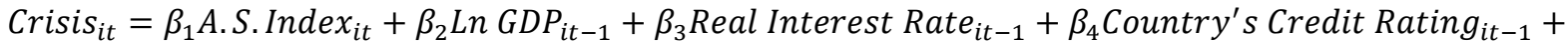
$\beta_{5}$ Govt. Fiscal Balance $_{i t-1}+\beta_{6}$ De Facto Ex. Rate Ft $-1_{1}+\beta_{7}$ Inflation $_{i t-1}+\beta_{8}$ Ln GDP per capita $_{i t-1}+$ $\boldsymbol{\beta}_{\mathbf{9}} \mathbf{X}+\varepsilon_{i t}$

where matrix $\mathbf{X}$ contains a set of additional variables added to the core regression.

The AS index has a significant and positive impact on the probability of a crisis. The coefficient on the AS index is positive and significant across different specifications of the regression. This means that a rise in asset shortages increases the probability of a crisis in the current year. Asset shortages could be a major source of crisis, by leading to a misallocation of assets. The imbalance between supply and demand, because it is not being addressed, results in assets appreciating beyond their fundamentals as illustrated in the previous section, leading to a crisis. Note that the coefficients of the real interest rate, income per capita, and growth rates have no statistically significant impact on the probability of crisis. As argued earlier, the sensitivity of asset prices to interest rates does not seem very large, with interest rates not leading to an equalization of demand and supply of assets. Interest rates in EMs can increase or reduce the probability of a crisis, depending on the credibility of monetary policy, which is high in some EMs and low in others. The development level of an economy does not make a crisis more likely. ${ }^{6}$

\footnotetext{
${ }^{6}$ The purchase of domestic financial assets - a proxy for financial integration with the world economy-by foreigners increases the probability of a crisis in an asset-shortage environment. In Table 8 , the connection between net positions in foreign and domestic assets is analyzed. The regression results show that only foreigners' holdings of domestic assets matter for the probability of a crisis occurring, and the coefficients are negative and significant at the 5 percent level, while ownership of foreign assets by domestic holders does not appear to matter in explaining crisis. The results imply that foreign investors raise the probability of crisis, since when they accumulate domestic assets, they, ceteris paribus, effectively increase domestic asset shortages, raising pressure for even higher asset prices.
} 
Table 8. Crisis Estimation Using the Probit Model

\begin{tabular}{|c|c|c|c|c|c|c|c|c|c|}
\hline \multirow[b]{2}{*}{ Independent Variables } & \multicolumn{9}{|c|}{ Crisis } \\
\hline & (1) & (2) & (3) & (4) & (5) & (6) & (7) & $(8)$ & (9) \\
\hline \multirow[t]{2}{*}{ AS Index } & $0.868^{\star \star \star}$ & $0.850^{\star \star \star}$ & $0.677^{* *}$ & $1.018^{\star *}$ & $0.920^{\star *}$ & $0.827^{\star *}$ & $1.052^{* \star \star}$ & $1.066^{\star \star \star}$ & $0.887^{\star \star *}$ \\
\hline & $(0.329)$ & $(0.326)$ & $(0.276)$ & $(0.440)$ & $(0.361)$ & $(0.385)$ & $(0.363)$ & $(0.389)$ & $(0.345)$ \\
\hline \multirow[t]{2}{*}{$\log$ of GDP (t-1) } & 0.113 & 0.083 & -0.001 & 0.265 & 0.116 & 0.356 & 0.046 & 0.0885 & 0.154 \\
\hline & $(0.173)$ & $(0.183)$ & $(0.107)$ & $(0.358)$ & $(0.184)$ & $(0.401)$ & $(0.115)$ & $(0.146)$ & $(0.215)$ \\
\hline \multirow[t]{2}{*}{ Real interest rate (t-1) } & 0.017 & 0.019 & 0.007 & 0.016 & 0.0179 & 0.009 & 0.018 & 0.0183 & 0.0150 \\
\hline & $(0.025)$ & $(0.025)$ & $(0.023)$ & $(0.029)$ & $(0.026)$ & $(0.047)$ & $(0.024)$ & $(0.025)$ & $(0.026)$ \\
\hline \multirow[t]{2}{*}{ Country's credit rating (t-1) } & $-0.580^{* *}$ & $-0.577^{* *}$ & $-0.439^{* *}$ & $-0.549^{*}$ & $-0.612^{* *}$ & $-0.696^{* *}$ & $-0.495^{*}$ & $-0.566^{* *}$ & $-0.594^{* *}$ \\
\hline & $(0.286)$ & $(0.281)$ & $(0.242)$ & $(0.316)$ & $(0.300)$ & $(0.344)$ & $(0.267)$ & $(0.280)$ & $(0.296)$ \\
\hline \multirow[t]{2}{*}{ Government deficit (t-1) } & -1.091 & -0.907 & -0.169 & 1.802 & -1.833 & 2.832 & -3.575 & -3.499 & -1.109 \\
\hline & $(8.596)$ & (8.287) & $(6.742)$ & $(9.750)$ & (8.759) & $(9.735)$ & $(7.516)$ & (7.955) & $(8.892)$ \\
\hline \multirow[t]{2}{*}{ De facto exchange rate $(\mathrm{t}-1)$} & $-0.386^{*}$ & $-0.384^{*}$ & $-0.335^{*}$ & $-0.426^{*}$ & $-0.444^{*}$ & -0.572 & $-0.418^{\star *}$ & $-0.435^{*}$ & $-0.383^{*}$ \\
\hline & $(0.217)$ & $(0.212)$ & $(0.190)$ & $(0.249)$ & $(0.248)$ & $(0.382)$ & $(0.210)$ & $(0.224)$ & $(0.224)$ \\
\hline Inflation $(\mathrm{t}-1)$ & $\begin{array}{l}-0.532 \\
(0.510)\end{array}$ & $\begin{array}{l}-0.466 \\
(0.520)\end{array}$ & $\begin{array}{l}-0.256 \\
(0.296)\end{array}$ & $\begin{array}{l}-0.768 \\
(0.854)\end{array}$ & $\begin{array}{l}-0.597 \\
(0.566)\end{array}$ & $\begin{array}{l}-1.050 \\
(0.901)\end{array}$ & $\begin{array}{l}-0.369 \\
(0.425)\end{array}$ & $\begin{array}{l}-0.507 \\
(0.498)\end{array}$ & $\begin{array}{l}-0.602 \\
(0.581)\end{array}$ \\
\hline Log of GDP per capita & $\begin{array}{l}-0.311 \\
(0.515)\end{array}$ & $\begin{array}{l}-0.227 \\
(0.535)\end{array}$ & $\begin{array}{l}-0.161 \\
(0.313)\end{array}$ & $\begin{array}{l}-0.833 \\
(1.126)\end{array}$ & $\begin{array}{l}-0.318 \\
(0.548)\end{array}$ & $\begin{array}{l}-0.853 \\
(1.102)\end{array}$ & $\begin{array}{l}-0.149 \\
(0.339)\end{array}$ & $\begin{array}{l}-0.266 \\
(0.440)\end{array}$ & $\begin{array}{l}-0.426 \\
(0.632)\end{array}$ \\
\hline Common law & & $\begin{array}{c}0.224 \\
(0.725)\end{array}$ & & & & & & & \\
\hline US interest rate (t-1) & & & $\begin{array}{l}0.324^{* *} \\
(0.165)\end{array}$ & & & & & & \\
\hline External debt & & & & $\begin{array}{c}0.412 \\
(0.374)\end{array}$ & & & & & \\
\hline Government debt & & & & & $\begin{array}{c}0.278 \\
(0.461)\end{array}$ & & & & \\
\hline Government revenue & & & & & & $\begin{array}{l}-2.916 \\
(2.407)\end{array}$ & & & \\
\hline Net domestic asset held by & & & & & & & $-10.35^{\star *}$ & & \\
\hline Foreign investors & & & & & & & $(4.459)$ & & \\
\hline $\begin{array}{l}\text { Net foreign asset held by } \\
\text { domestic investors }\end{array}$ & & & & & & & $\begin{array}{l}-5.645 \\
(3.698)\end{array}$ & & \\
\hline Net domestic/foreign assets & & & & & & & & $-8.002^{\star \star}$ & \\
\hline held by domestic investors & & & & & & & & $(3.950)$ & \\
\hline REER & & & & & & & & & $\begin{array}{l}-0.0001 \\
(0.0003)\end{array}$ \\
\hline Pseudo-R-squared & 0.598 & 0.598 & 0.619 & 0.633 & 0.627 & 0.626 & 0.624 & 0.619 & 0.600 \\
\hline Observations & 289 & 289 & 289 & 272 & 289 & 287 & 289 & 289 & 289 \\
\hline Number of id & 32 & 32 & 32 & 32 & 32 & 32 & 32 & 32 & 32 \\
\hline
\end{tabular}




\section{Current Account}

In this final section, an empirical estimation of the relationship between asset shortages and the current account balances is undertaken. Caballero (2006) has argued that the current global imbalance reflects the consequence of the shortage of safe assets in EMs. In other words, EMs are unable to generate enough assets to store their new-found wealth. On the other hand, advanced economies - notably the US and UK - are able to generate such assets easily, reflecting the strength of their capital markets. With increased liberalization of capital markets, asset shortages in EMs have spillover effects, with excess savings being channeled to overseas economies that are better able to generate financial assets. As we argued earlier in this paper, at the micro level, many private enterprises in EMs are credit constrained. To finance their future investment, instead of issuing financial assets to raise funds on capital markets, they have to raise financing through internal savings or request it overseas. The rapid growth of these self-financed firms creates an artificial lack of domestic investment opportunities for banks. As a consequence, a growing share of domestic savings has to be invested abroad, leading to a current account surplus (Song, Storesletten, and Zilibotti, 2009).

To avoid endogeneity problems, system-GMM is again used for the estimation. We test for unit roots in the current account balance using the Im, Pesaran, and Shin (2003) panel unit root test. Because the test suggests that the null hypothesis cannot be rejected, the current account balance contains a unit root. The null hypothesis in its first difference can be rejected (Table 9), leading to the use of change in the current account as the dependent variable.

\section{Table 9. Im-Pesaran-Shin Unit Root Test}

\begin{tabular}{l|cc}
\cline { 2 - 3 } & \multicolumn{2}{c}{ Current Account Balance } \\
\cline { 2 - 3 } Test statistics & Level & First differences \\
P-value & -1.308 & -2.260 \\
\hline${ }^{* * *} p<0.01,{ }^{* *} p<0.05,{ }^{*} p<0.1$ & 0.679 & $0.000^{* \star *}$ \\
\hline
\end{tabular}

The starting point is to regress the change in the current account balance on a set of core variables selected according to the literature, with additional regulation variables added separately. Moreover, by definition, the real economy factors that drive current account balances are orthogonal to the determinant of financial asset issuances; hence, by excluding the real side factors in our regression, the results will not be biased. The following regression is estimated:

$\Delta$ Current Account Balance $_{i t}=\beta_{1} \Delta$ Current Account Balance $_{i t-1}+\beta_{2}$ A. S. Index It $_{i t}+\beta_{3} \Delta$ Inflation $_{i t}+$ $\beta_{4}$ Openness $_{i t}+\beta_{5} \Delta$ Real Interest Rate ${ }_{i t}+\beta_{6}$ RER $_{i t}+\beta_{7} \Delta$ Government Fiscal Balance $_{i t}+$ $\beta_{8} \Delta$ World GDP Growth $_{i t}+\boldsymbol{\beta}_{\mathbf{9}} \mathbf{X}+\varepsilon_{i t}$

The core regression includes the impact of change in the current account lagged by one period, the AS index, openness, change in inflation and real interest rate, real exchange rate, change in government fiscal balance, and world GDP growth. Subsequent regressions include GDP per capita as a measure of the wealth of individuals, change in a country's 
credit rating, legal origin, change in corruption, US interest rate, crisis introduced as a dummy variable, government stability, and exchange rate risk.

The impact of asset shortages on the current account is positive and statistically significant (Table 10). This is consistent with our analysis that EMs' inability to generate enough financial assets relative to domestic savings leads them to invest in overseas financial assets. The export of capital results in a current account surplus. This finding is robust to different specifications and inclusion of different explanatory variables. This empirically supports the idea proposed by Caballero (2006), though his focus mainly is on asset shortages for safe assets, whereas our analysis argues that asset shortages in general, are the problem. The results do not change with the inclusion of other dependent variables, implying robustness. The evidence shows that rising asset shortages lead to mounting current account surpluses. One way for EMs to address the current account surpluses is to increase the supply of financial assets, through improving economic fundamentals further and improving the domestic investment environment, for instance. 
Table 10. Estimating Changes in the Current Account Using System-GMM

\begin{tabular}{|c|c|c|c|c|c|c|c|c|c|}
\hline \multirow[b]{2}{*}{ Independent. } & \multicolumn{9}{|c|}{$\Delta$ Current Account Balance } \\
\hline & (1) & $(2)$ & (3) & (4) & (5) & (6) & (7) & $(8)$ & (9) \\
\hline$\Delta$ C.A. $(\mathrm{t}-1)$ & $\begin{array}{l}-0.025 \\
(0.107)\end{array}$ & $\begin{array}{l}-0.037 \\
(0.124)\end{array}$ & $\begin{array}{l}-0.029 \\
(0.111)\end{array}$ & $\begin{array}{l}-0.033 \\
(0.114)\end{array}$ & $\begin{array}{l}-0.025 \\
(0.107)\end{array}$ & $\begin{array}{l}-0.043 \\
(0.106)\end{array}$ & $\begin{array}{l}-0.015 \\
(0.108)\end{array}$ & $\begin{array}{l}-0.024 \\
(0.106)\end{array}$ & $\begin{array}{l}-0.021 \\
(0.105)\end{array}$ \\
\hline AS index & $\begin{array}{l}0.007^{* *} \\
(0.003)\end{array}$ & $\begin{array}{l}0.006^{\star *} \\
(0.003)\end{array}$ & $\begin{array}{l}0.007^{* *} \\
(0.003)\end{array}$ & $\begin{array}{l}0.007^{\star *} \\
(0.004)\end{array}$ & $\begin{array}{l}0.007^{* *} \\
(0.003)\end{array}$ & $\begin{array}{l}0.007^{* *} \\
(0.004)\end{array}$ & $\begin{array}{l}0.007^{* *} \\
(0.003)\end{array}$ & $\begin{array}{c}0.007^{* *} \\
(0.00353)\end{array}$ & $\begin{array}{l}0.007^{* *} \\
(0.003)\end{array}$ \\
\hline$\Delta$ Inflation & $\begin{array}{c}0.013^{* * *} \\
(0.002)\end{array}$ & $\begin{array}{c}0.013^{* * *} \\
(0.002)\end{array}$ & $\begin{array}{c}0.013^{* * *} \\
(0.002)\end{array}$ & $\begin{array}{c}0.015^{\star * *} \\
(0.002)\end{array}$ & $\begin{array}{c}0.014^{* * *} \\
(0.002)\end{array}$ & $\begin{array}{c}0.012^{* * *} \\
(0.002)\end{array}$ & $\begin{array}{c}0.014^{* * *} \\
(0.002)\end{array}$ & $\begin{array}{l}0.0149^{* * *} \\
(0.00194)\end{array}$ & $\begin{array}{c}0.016^{* * *} \\
(0.002)\end{array}$ \\
\hline Openness & $\begin{array}{c}-0.00005^{* *} \\
(0.00002)\end{array}$ & $\begin{array}{l}-0.00008 \\
(0.00005)\end{array}$ & $\begin{array}{l}-0.00004^{*} \\
(0.00002)\end{array}$ & $\begin{array}{c}0.00001 \\
(0.00004)\end{array}$ & $\begin{array}{c}-0.00005^{* *} \\
(0.00003)\end{array}$ & $\begin{array}{c}-0.00005^{* *} \\
(0.00003)\end{array}$ & $\begin{array}{l}-0.000001 \\
(3.39 e-05)\end{array}$ & $\begin{array}{c}0.00003 \\
(0.00003)\end{array}$ & $\begin{array}{c}0.00001 \\
(0.00003)\end{array}$ \\
\hline$\Delta \mathrm{R}$. interest & $\begin{array}{c}0.001 \\
(0.001)\end{array}$ & $\begin{array}{c}0.001 \\
(0.001)\end{array}$ & $\begin{array}{c}0.001 \\
(0.001)\end{array}$ & $\begin{array}{c}0.001 \\
(0.001)\end{array}$ & $\begin{array}{c}0.00117 \\
(0.000910)\end{array}$ & $\begin{array}{c}0.002 \\
(0.0008)\end{array}$ & $\begin{array}{c}0.00109 \\
(0.00101)\end{array}$ & $\begin{array}{c}0.001 \\
(0.001)\end{array}$ & $\begin{array}{c}0.001 \\
(0.001)\end{array}$ \\
\hline RER & $\begin{array}{c}- \\
0.000001^{* * *} \\
(0.0000004)\end{array}$ & $0.000001^{* \star *}$ & $0.000001^{* \star *}$ & $-0.000001^{* * *}$ & $-0.000001^{* * *}$ & $-0.000001^{* * *}$ & $-0.000001^{* * *}$ & $-0.000001^{* *}$ & $-0.000001^{* *}$ \\
\hline $\begin{array}{l}\Delta \text { Government } \\
\text { fiscal balance }\end{array}$ & $\begin{array}{l}0.004^{*} \\
(0.002)\end{array}$ & $\begin{array}{l}0.005^{\star} \\
(0.002)\end{array}$ & $\begin{array}{c}0.005^{*} \\
(0.002)\end{array}$ & $\begin{array}{l}0.005^{*} \\
(0.002)\end{array}$ & $\begin{array}{c}0.005^{*} \\
(0.00243)\end{array}$ & $\begin{array}{l}0.005^{*} \\
(0.003)\end{array}$ & $\begin{array}{l}0.005^{*} \\
(0.002)\end{array}$ & $\begin{array}{l}0.005^{*} \\
(0.002)\end{array}$ & $\begin{array}{c}0.005^{*} \\
(0.00239)\end{array}$ \\
\hline $\begin{array}{l}\Delta \text { World GDP } \\
\text { growth } \\
\text { GDP per } \\
\text { capita }\end{array}$ & $\begin{array}{l}0.080^{*} \\
(0.044)\end{array}$ & $\begin{array}{c}0.077^{*} \\
(0.042) \\
0.0000004 \\
(0.0000004)\end{array}$ & $\begin{array}{l}0.082^{*} \\
(0.045)\end{array}$ & $\begin{array}{l}0.084^{*} \\
(0.045)\end{array}$ & $\begin{array}{l}0.080^{*} \\
(0.0440)\end{array}$ & $\begin{array}{c}0.056 \\
(0.043)\end{array}$ & $\begin{array}{c}0.0695 \\
(0.0458)\end{array}$ & $\begin{array}{l}0.090^{*} \\
(0.046)\end{array}$ & $\begin{array}{l}0.089^{*} \\
(0.045)\end{array}$ \\
\hline $\begin{array}{l}\Delta \text { Country's } \\
\text { credit rating }\end{array}$ & & & $\begin{array}{l}-0.009^{*} \\
(0.005)\end{array}$ & & & & & & \\
\hline regulation & & & & $\begin{array}{l}-0.008 \\
(0.005)\end{array}$ & & & & & \\
\hline Common law & & & & & $\begin{array}{c}0.00237 \\
(0.00356)\end{array}$ & & & & \\
\hline Crisis dummy (t-1) & & & & & & $\begin{array}{c}0.040^{* * *} \\
(0.012)\end{array}$ & & & \\
\hline US interest rate & & & & & & & $\begin{array}{l}-0.002 \\
(0.001)\end{array}$ & & \\
\hline Ex. rate risk & & & & & & & & $\begin{array}{l}-0.001^{* *} \\
(0.0004)\end{array}$ & \\
\hline Term of trade & & & & & & & & & $\begin{array}{l}-0.0001^{*} \\
(0.00003)\end{array}$ \\
\hline $\begin{array}{l}\text { Arellano-Bond test } \\
\text { for } A R(2) \text { in first diff }\end{array}$ & 0.070 & 0.070 & 0.090 & 0.070 & 0.070 & 0.070 & 0.077 & 0.070 & 0.070 \\
\hline $\begin{array}{l}\text { Hansen test of } \\
\text { overide restrictions }\end{array}$ & 1.000 & 1.000 & 1.000 & 1.000 & 1.000 & 1.000 & 1.000 & 1.000 & 1.000 \\
\hline
\end{tabular}

Robust standard errors in parentheses

${ }^{* * *} p<0.01,{ }^{* *} p<0.05,{ }^{*} p<0.1$ 


\section{CONCLUSION AND Policy IMPlications}

We started the paper by empirically estimating the impact of asset shortages in EMs on key macroeconomic variables. First, we argued that asset shortages have a negative impact on economic growth in the long run. Second, asset shortages are a significant source of asset bubbles over time and thereby increase the probability of a crisis. Last, asset shortages are a leading explanatory variable in current account surpluses of emerging markets. The macroeconomic implications are grave, and must be addressed to avoid macroeconomic instability going forward.

Asset shortages are not only dangerous for the macroeconomic stability of EMs, but are also a cause of the present global imbalances. Shortages of financial assets in EMs generate permanent current account surpluses, which are clearly not sustainable. Eventually, for creditors to repay their debt, they will either have to generate current account surpluses, or the assets owned by EMs in AEs will have to fall in value (through exchange rate adjustment for instance).

Given the danger that asset shortages pose for EMs and global stability more generally, it is crucial for policy makers to tackle the problem sooner rather than later. The arguments do not apply just to EMs, but even more so to frontier markets - the subset of emerging markets with small and illiquid market capitalizations - because the consequences of asset shortages are particularly strong there.

\section{Policy prescriptions}

Policies that could help reduce asset shortages include the following (see Chen and Imam, 2011, for other policies to address the asset shortage imbalance.):

- Deepen capital markets. To spur growth in the supply of financial assets, it is crucial to deepen capital markets further. More efficient capital markets would increase access to financing for the private sector, lower the cost of financing, distribute risk, and support long-term growth. Many countries have developed alternative markets for mid-cap companies in the early stages of development. Inspired by the success of AIM (Alternative Investment Market) in London, which allows smaller companies to float shares with a more flexible regulatory system, some emerging markets have, with varying degrees of success, managed to develop such markets. For example, Peru recently simplified the issuance of securities by establishing a "fast track" registration process for public offerings by accredited investors. However, in order for this to work, the country has to have an investor base willing to take risks and a critical mass of companies with the potential to grow rapidly.

- Improve regulation. Authorities in emerging markets should clarify legislation and modify regulations to spur the growth of new financial assets. In Latin America, for instance, regulatory restrictions on the investment of pension funds in nontraditional instruments (private equity, real estate, lower-rated fixed income products, etc.) and illiquid assets in the stock market have limited the opportunities for growth in such non-traditional assets. Liberalizing these investment restrictions would encourage 
companies to issue more non-traditional financial assets, thereby widening the investment universe.

Regulations should address not only the demand side but also encourage the supply side of financial assets. With a rising rate of urbanization and growing income levels, the demand for housing - and financing for it - is rising rapidly. In most emerging markets, however, the market for covered mortgage loans is underdeveloped, given the vague legal and regulatory framework with regard to the collateral and matching requirements for covered bonds, valuation issues, and their treatment of in the case of bankruptcy. Addressing these issues could pave the way for the growth of covered bond markets.

Similar reforms may be needed to create an asset-backed securities (ABS) market for mortgages. A successful ABS market for mortgages could open the door for other assets such as credit cards and auto loans to become securitized, thus expanding the list of financial assets.

Governments should also develop comprehensive policies to support new companies by fostering private equity and venture capital industries. This could take the form of tax incentives to invest in high risk asset classes, or it could complement private investment through public sector co-investment in some ventures targeting earlier stages of development. Such policies have been successfully implemented in Brazil and South Africa.

The business environment for publicly listed companies should likewise be improved. Encouraging entrepreneurs to expand by using capital markets is an important step in increasing asset supply. Too often, companies are discouraged from going public because of the regulatory hurdles and increased costs that inevitably result.

In addition, rules could be set in place to enforce a minimum amount of assets that must be listed on a stock exchange. In 2010, India's Finance Ministry announced new rules for companies listed on Indian bourses, requiring them to make available, within 5 years, a minimum of 25 percent of equity, as opposed to the existing 10 percent. Such a move also raises liquidity, and thereby reduces volatility.

Countries with many state-owned enterprises could also launch a program to list and privatize, as Malaysia is doing. While privatization per se is not a panacea that will necessarily improve the productivity of state-owned enterprises, it does tend to improve the governance and profitability of companies. And privatization has the added benefit of increasing the supply of financial assets.

Finally, regulators could remove or reduce the limit on how much institutional investors are allowed by law to invest overseas. This would allow the system to lessen the excessive exposure to domestic systemic risk and the risk of domestic security prices moving too far from the fundamentals. Local markets tend to be uncorrelated with international markets, and thus diversification is likely to pay off. 
- $\quad$ Reduce savings. Partly because individuals behave in a precautionary manner, emerging markets have large national savings rates. High saving rates in China, for instance, are said to reflect high individual risk related to the cost of health, retirement, and education. Consequently, one way of reducing savings - and helping correct the asset shortage problem - is to strengthen the social safety net. This is why in 2008, China expanded the Chinese state health care system 'Yi Bao' to 229 cities.

In countries where the fiscal position is strong and infrastructure needs are acute, raising infrastructure investment, financed through issuing financial assets, is another way of reducing national savings. Such a strategy would have obvious positive spillovers for the rest of the economy.

\section{No magic bullet}

There is no magic bullet that will correct asset shortages. The comprehensive set of reforms described here will certainly help reduce macroeconomic imbalances and financial instability. But tackling the problem of asset shortages will also further stimulate the broader development of emerging markets by spurring investment, perfecting the allocation of resources, and reducing the likelihood of bubbles. 


\section{REFERENCES}

Bosworth, Barry, and Susan M. Collins, 2003, "The Empirics of Growth: An Update," Brookings Papers on Economic Activity, 2, Brookings Institution, pp. 113-206.

Brandt, Loren, Johannes Van Biesebroeck and Yifan Zhang. 2009 "Creative Accounting or Creative Destruction? Firm-level Productivity Growth in Chinese manufacturing". NBER Working Paper Series 15152, (Cambridge: National Bureau of Economic Research)

Caballero, Ricardo, 2006 "On the Macroeconomics of Asset Shortages” MIT mimeo

Caballero, Ricardo, Emmanuel Farhi, and Pierre-Olivier Gourinchas, 2008, “An Equilibrium Model of 'Global Imbalances' and Low Interest Rates" American Economic Review, Vol. 98, pp. 358-393

Canning, David, and Peter Pedroni, 2008, "Infrastructure, Long-Run Economic Growth and Causality Tests for Cointegrated Panels." The Manchester School Vol. 76, pp. 504-527

Chen, Jiaqian and Patrick Imam, 2011, "Causes of Asset Shortages in Emerging Markets" IMF Working Paper No.114 (Washington: International Monetary Fund)

Chinn, Menzie, and Hiro Ito 2008 "A New Measure of Financial Openness" Journal of Comparative Policy Analysis, Vol.10, pp. 309-322

Corcos, Gregory, Massimo Del Gatto, Giordano Mion and Giammarco Ottaviano, 2011, "Productivity and Firm Selection: Quantifying the 'New' Gains from Trade", FEEM Working Papers No. 379

Durlauf, Steven, Paul Johnson, and Jonathan Temple, 2005, "Growth Econometrics" in Aghion, P., Durlauf, S. (eds.), Handbook of Economic Growth, Amsterdam, North-Holland.

GFSR, 2005, "Development of Corporate Bond Markets in Emerging Market Countries" (Washington DC, International Monetary Fund)

GFSR, 2010, "Resolving the Crisis Legacy and Meeting New Challenges to Financial Stability" (Washington DC, International Monetary Fund)

Hausmann, Ricardo and Ugo Panizza, 2010, "Redemption or abstinence? Original Sin, Currency Mismatches and Counter-Cyclical Policies in the New Millennium", Centre for International Development at Harvard University Working Paper No. 194

Im Kyung So, Hashem Pesaran, and Yongcheol Shin, 2003, "Testing for Unit Roots in Heterogeneous Panels.” Journals of Econometrics Vol. 115, pp. 53-74

King, Robert G., and Ross Levine (1993a). "Finance and Growth: Schumpeter Might be Right." Quarterly Journal of Economics Vol. 108, pp.717 - 737 
King, Robert G., and Ross Levine (1993b). "Finance, Entrepreneurship and Growth." Journal of Monetary Economics Vol. 32, pp.513 - 542

Laeven, Luc and Fabian Valencia. 2008. "Systemic Banking Crisis: A New Database." IMF Working Paper No. 224

La Porta, Rafael, Florencio Lopez-de-Silanes, Andrei Shleifer, and Robert W. Vishny. 1997. "Legal Determinants of External Finance." Journal of Finance Vol. 52, pp.1131-50 1998. "Law and Finance.” Journal of Political Economy Vol. 106, pp.1135-55

Levine, Ross, and David Renelt, 1992, "A Sensitivity Analysis of Cross-Country Growth Regressions,” American Economic Review, Vol. 82, pp. 942-63

Melitz, Marc, 2003 "The Impact of Trade on Intra-Industry Reallocations and Aggregate Industry Productivity," Econometrica, Vol. 71, pp. 1695-1725

Pedroni, Peter (1999). "Critical Values for Co-integration Test in heterogeneous Panels with Multiple Regressors", Oxford Bulletin of Economics and Statistics, Vol. 61, pp. 653 - 670

Pedroni, Peter (2004). "Panel Co-integration; Asymptotic and Finite Sample Properties of pooled Time Series Tests, With an Application to the PPP Hypothesis", Econometric Theory, Vol. 20, pp. 597-625

Rajan, Raghuram, 2006, "Investment Restraint, the Liquidity Glut, and Global Imbalances" http://www.imf.org/external/np/speeches/2006/111506.htm

Reinhart, Carmen M., and Kenneth S. Rogoff, 2004, "Serial Default and the "Paradox" of Rich to Poor Capital Flows." NEBR Working Papers 10296, National Bureau of Economic Research

Reinhart, Carmen M., Kenneth S. Rogoff, and Miguel A. Savastano, 2003. "Debt Intolerance." NEBR Working Paper No. 9908, National Bureau of Economic Research

Roodman, David Malin. (2006). "How to Do xtabond2: An Introduction to "Difference" and "System" GMM in Stata." Center for Global Development Working Paper No. 103

Sala-i-Martin, Xavier, 1997, "I just Ran Two Million Regressions," American Economic Review Papers and Proceedings, Vol.87, pp. 178-183,

Song Zheng, Storesletten Kjetil, and Fabrizio Zilibotti. (2011) "Growing Like China" American Economic Review, Vol.101, pp.196-233

Tirole, Jean. 1985, “Asset Bubbles and Overlapping Generations", Econometrica, Vol. 53, pp.1499-1528. 


\section{Appendix 1. Theoretical Model}

In this section, we develop a small open economy model to illustrate how asset shortages in EMs lead to lower economic growth, an increase in local asset prices, and current account surpluses (see Chen, 2011). The starting point is to divide the world into two regions: Emerging Markets (EM) and Advanced Economies (AE), with the focus being on the former group. The key feature of the model is that it focuses on region EM's inability to supply financial assets to domestic savers. The inability to generate sufficient instruments locally, from safe triple

A-rated store-of-value instruments to riskier bonds and equity, increases EM savers' demand for overseas investable instruments. If distortions, such as regulations, restrict the outflow, the excess demand for investable assets will spill over into the domestic economy. EMs' inability to create a large set of financial assets will (i) starve domestic firms of capital, thus slowing their growth; (ii) push up domestic asset prices; and (iii) create a current account surplus.

\section{The Basic Structure--A Small Open Economy}

The benchmark framework consists of multiple open economies, characterized by an overlapping generation structure. This structure provides scope for both international and intergenerational borrowings. In each region, a final good producer manufactures one type of tradable final good $\left(Y_{E M}, Y_{A E}\right)$, with each final good produced with intermediate goods that are not traded across borders. Households own the intermediate good producing firms. In this world, borrowing ability matters prior to production; each potential new firm needs to make a fixed investment, which is financed by borrowing against the present discounted value of future cash flows. The fraction of the present value of future profits that a potential entrant can pledge is the borrowing constraint. Furthermore, the weighted average of all agents' borrowing ability within each region $(\mathrm{EM}, \mathrm{AE})$ is defined as the financial development in that region. The inability to supply financial assets is therefore akin to a tightening of borrowing abilities.

\section{Consumption}

Time is evolving continuously, with infinitesimal agents born at a rate $\rho$ per unit time and dying at the same rate, leading to a constant population mass equal to one. Consider an agent in region EM, who optimally decides the consumption of the final good and savings, where the only saving vehicles are the assets issued by the intermediate firms (more on this below). Following Blanchard (1985), we assume that private markets provide insurance, and agents will contract to have all of their wealth return to the life insurance company contingent on their death, such that agents do not need to worry about longevity risk. If an agent's wealth is $\omega$, they will receive $\rho \omega$ if they do not die, and pay $\omega$ if they die. By assuming agents have logarithmic utility functions, optimal aggregate consumption and saving (wealth) dynamics have the following characteristics:

$$
\dot{C}_{t}=(r-\tau) C_{t}-\rho(\rho+\tau) W_{t}
$$




$$
\dot{W}_{t}=r W_{t}+A_{t}-C_{t}
$$

where, $A_{t}$ denotes aggregate (across all household) income at time $t, W_{t}$ is the total wealth (saving) at time $t, C_{t}$ is the aggregate consumption, while $r$ is the exogenous foreign interest rate and $\tau$ is the (domestic) time discounting factor.

The final goods produced in each region EM and AE, are traded across borders. Therefore, the optimal intra-temporal consumption decision for an agent in region $\mathrm{EM}$ or $\mathrm{AE}$ is:

$$
c_{i, t}^{j}=\left(\frac{P_{i, t}^{j}}{P_{t}^{j}}\right)^{-\theta} C_{t}^{j} \quad i, j=E M, A E
$$

where, $c_{i, t}^{j}$ is the consumption for final good $i$ at time $t$ in region $j, P_{i, t}^{j}$ is the price of good $i$ at time $t, \theta$ is the elasticity of substitution between goods and $P_{t}^{E M}=P_{t}^{A E}=\left(\frac{1}{2} p_{E M, t}^{1-\theta}+\right.$ $\left.\frac{1}{2} p_{A E, t}^{1-\theta}\right)^{\frac{1}{1-\theta}}$ is the price index of the consumption bundle $C_{t}^{j}$ in region EM and AE, which we normalize to 1 . Since households in each region consume the same basket of final goods, $P_{t}^{E M}=P_{t}^{A E}$.

\section{Production}

Let us begin by focusing on the EM region. The final good producer's production technology uses 0 to $w_{E M}$ intermediate goods as inputs to produce one unit of final $\operatorname{good} Y_{E M}$ :

$$
Y_{E M}=w_{E M}\left(\int_{0}^{1} y_{E M}(i)^{\frac{\theta-1}{\theta}} d i\right)^{\frac{\theta}{\theta-1}}
$$

where, $Y_{E}$ denotes the final good produced in region EM, $w_{E M}$ refers to the number of intermediate good producing firms in the region, and $y_{E M}(i)$ is the intermediate good with $i$ input for production. The same applies for the final good produced in region AE.

The final good producer chooses the quantity of intermediate inputs $y_{E M}(i)$ to minimize the total cost function subject to a given level of output $\bar{Y}_{E M}$ :

$$
\begin{gathered}
\min _{\mathrm{y}_{E M}(\mathrm{i})} w_{E M} p_{E M}(i) y_{E M}(i) \\
\text { s.t. } Y_{E M} \geq \bar{Y}_{E M} \\
y_{E M}^{*}(i)=\frac{1}{w_{E M}}\left(\frac{P_{E M}(i)}{P_{E M}}\right)^{-\theta} \bar{Y}_{E M}
\end{gathered}
$$

Intermediate good producing firms use only labor as the factor of input. Under monopolistic competition, they set the prices at a constant mark-up over the marginal costs: $p_{E M}(i)=$ 
$\left(\frac{\theta-1}{\theta}\right)\left(\frac{v}{\varphi(i)}\right)$, where $\mathrm{v}$ is the wage rate determined by labor market clearing condition ${ }^{7}, \varphi(i)$ is firm $i^{\prime} s$ specific productivity parameter. Intermediate firms take the demand as given from the final good producer, generating a profit function at time $t$ that has the following form:

$$
\pi_{E M, t}^{*}(i)=\left(\frac{v^{1-\theta}}{\theta-1}\left(\frac{\theta}{\theta-1}\right)^{-\theta}\right) \frac{\varphi_{E M}^{\theta-1}(i)}{w_{E M, t}}\left(\frac{P_{E M, t}(i)}{P_{E M, t}}\right)^{-\theta} \bar{Y}_{E M, t}
$$

\section{Intermediate Firm Entry Decision}

There is a large (unbounded) pool of prospective entrants into intermediate good production. We assume that each firm is owned by an agent; initially a firm (or agent) draws a productivity parameter $\varphi \geq \varphi_{\min }$ from a common distribution $g(\varphi) \cdot g(\varphi)$ has positive support over $\left[\varphi_{\min }, \infty\right)$ and has corresponding cumulative distribution $G(\varphi)$. To enter, each potential entrant has to make an initial sunk investment in the form of a fixed entry cost $F_{E M}>0$. To finance this initial fixed cost, each firm needs to borrow against its present discounted value of future profits. Therefore, each potential entrant, given his productivity parameter, knows the entry cost and the fraction he can borrow, and all firms simultaneously decide whether to begin production or not.

In summary, a potential entrant will enter intermediate good production if and only if he makes non-negative profit by entering and meets the initial financial requirement. Consider an agent with borrowing ability $\delta$, meaning he can pledge $\delta$ fraction of discount value of future profits. In that case, the entry decision rule is given by:

$$
\delta_{E M} \pi_{\infty}(i)-F_{E M} \geq 0
$$

where $\pi_{\infty}(i)$ denotes the present discounted value of future profits for a potential intermediate firm $i$.

$$
\pi_{\infty}(i)=\int_{t}^{\infty} \pi_{s}(i) e^{-\int_{t}^{s}(r+\rho) d \tau} d s
$$

Furthermore, let $\Pi_{t}$ denote the aggregate (across all intermediate firms) profit at time $t$.

$$
\Pi_{t}=\int_{0}^{1} \pi_{S}(i) d i
$$

The reservation productivity $\varphi_{E M}^{*}$ is characterised by the following equation, implying that all potential entrants with productivity draw higher than $\varphi_{E M}^{*}$ will enter and begin intermediate goods production.

${ }^{7}$ Labor market equilibrium condition imposes: $w_{E M} \int_{0}^{1} l_{E M}(i) d i=L=1$.

${ }^{8}$ Note, the first condition states: $\pi_{\infty}(i)-F_{E M} \geq 0$, since $\delta<1$, therefore this condition is always satisfied if firm meets its borrowing condition. 


$$
\varphi_{E M, t}^{*}=\left(\frac{F_{E M}}{\delta_{E M}}\left(\frac{v^{1-\theta}}{\theta-1}\right)^{-1}\left(\frac{\theta}{\theta-1}\right)^{\theta}\left(\int_{t}^{\infty} w_{E M, s} p_{E M, S}^{\theta-1} C_{E M, s} e^{-\int_{t}^{s}(r(\tau)+\rho) d \tau}\right)^{-1}\right)^{\frac{1}{\theta-1}}
$$

The Nash Equilibrium number of firms in the market is then given by:

$$
\mathrm{w}_{E M, t}=1-G\left(\varphi_{E M, t}^{*}\right)
$$

\section{Asset market}

The only storage where agents can deposit their savings is the corporate bonds issued by intermediate firms (when they finance the initial fixed $\operatorname{cost} F_{E M}$ ). The return on the corporate bond equals the dividend price ratio $\frac{\delta_{E M} \mathrm{~V}_{E M}}{V_{E M}}$ plus the capital gain $\frac{\dot{\mathrm{V}}_{E M}}{V_{E M}}$. This return is equal to the world interest rate $r$ (which is exogenously given). At time $t$, this relationship is given by:

$$
r_{t} V_{E M, t}=\delta_{\mathrm{EM}, \mathrm{t}} \mathrm{V}_{E M, t}+\dot{V}_{E M, t}
$$

Since we investigate the asset shortage problems in EMs, it is natural to focus on a 'small' open economy, suggesting that the EM region takes the interest rate as given, or put differently, the EM region is too small so it cannot affect the world equilibrium interest rate $r$.

Furthermore, we assume that, within each region, there exists a local asset called L, which pays the same interest rate as the corporate bond. However, while asset L is not traded on the international market, meaning it can only be purchased by locals, corporate bonds can be purchased by both locals and foreigners. Furthermore, for reasons of riskiness, liquidity, and home bias, we assume each agent has a strict preference as to the type of asset in which he chooses to store his savings.

Assumption 1 (Preference of Assets): Each agent has a strict preference within different asset classes. In particular, they will firstly satisfy their needs with domestic corporate bonds that can be traded internationally, due to higher liquidity, followed by local asset L, because of home bias, and lastly foreign bonds.

Moreover, due to the inability to supply assets, we assume that local asset supply is capped at $\bar{L}$.

Finally, we introduce the definition of current account balance in region EM:

\section{Calibration}

$$
C A_{t}^{E M}=\dot{W}_{E M, t}-\dot{V}_{E M, t}
$$

Let us now calibrate the parameters for the EM region. For simplicity, we assume standard preference parameters, with the inter-temporal elasticity of substitution being the same for the final goods producer and household's final good consumption, which is fixed at $\theta=$ 2.1. The time discount factor for the household is set at $\tau=0.02$ to match the average 
median real interest rate in our EM country sample between 2002 and 2010. The productivity $\varphi$ follows a Pareto distribution ${ }^{9}$, with shape parameter $\alpha$ equal to 2.6 and the minimum productivity set to equal 0.2 . These assumptions follow Corcos, Gatto, Mion and Ottaviano (2011), where they show that Pareto distribution closely fits the observed firm productivity distribution, and using a large firm level dataset from EM and AE, they estimate shape parameter $\alpha$ across different manufacturing industries. The exogenous entry and exit rate is calibrated to 5.5 percentage points, which was calculated as the (yearly) average of the firm entry and exit in EMs between 2002 and 2006 for a country like China (see also Brandt, Biesebroeck and Zhang, 2009). The initial fixed cost $\left(F_{E M}\right)$ is set to equal 0.32 , which is calibrated to the ratio between total fixed investments as a share of total output across EM manufacturing industries. The world interest rate is assumed equal to 3 percentage points. Finally, since it is difficult to measure borrowing abilities directly, we calibrate the value of $\delta_{\mathrm{EM}}=0.12$ following Caballero, Farhi and Gourinchas (2008).

Given this initial calibration in region EM, we now explore a few scenarios, which we will lay out in the parameter calibrations in the $\mathrm{AE}$ region.

\section{Quantitative Analysis--An Asset Supply Shock}

We begin with the analysis of a temporary collapse in $\delta_{\mathrm{EM}}$. This shock is analogous to the existence of asset shortages in region EM when investable asset growth lags behind savings growth. This could be spurred by structural reforms that facilitate entrepreneurship. In order to reveal the impacts and mechanisms of this shock, we assume that both region EM and AE start in the same steady state prior the shock. Put differently, all the results are driven by the shock.

Assumption 2 (Initial Conditions): The world is initially symmetric, more specifically, $\delta_{\mathrm{EM}}=\delta_{\mathrm{AE}}$, implying no initial asset shortage across regions. Suppose now, unexpectedly at $\mathrm{t}=0, \delta_{\mathrm{EM}}$ drops temporally to $\delta_{\mathrm{EM}}<\delta_{\mathrm{AE}}$. The fall in $\delta_{\mathrm{EM}}$ in general could result from a structural reform or a change in monetary policy, for instance (see Chen and Imam, 2011, for a detailed analysis of asset shortages). After the shock, asset shortages appear in region EM.

Note that the definition for current account in this paper excludes unexpected capital gains and losses from international positions. It is not of relevance, since at date 0 , agents are assumed not to be holding international assets. Also note that, since $C A_{t}^{E M}+C A_{t}^{A E}=0$, by characterizing the CA of EM, by default we also describe the CA of AE. Henceforth, we will focus on describing the behavior of $C A_{t}^{E M}$, with the understanding that this concept describes features of the global equilibrium rather than EM-specific features. ${ }^{10}$

\footnotetext{
${ }^{9}$ This is a common assumption made in the international trade literature, building on the Melitz (2003) model which requires an assumption on the productivity parameter distribution. Corcos, Gatto, Mion and Ottaviano (2011) empirically tested the Pareto distribution, and suggest it fits the actual productivity data well.
}

\footnotetext{
${ }^{10}$ Intuitively, before the shock, when domestic corporate bond supply is greater or equal to domestic savings, domestic investors don't have a strong preference to hold local assets. After the shock, when saving increases,
}

(continued...) 
One caveat, standard models imply that capital flows from low to high growth economies; we argue that this conclusion does not carry over to a situation in which productive agents have limited ability to generate assets in order to carry out investment. In particular, the inability to generate assets in the EM region implies an uphill capital flow, as illustrated in empirical work by Lucas ("Lucas paradox").

Figure 1 characterizes the path for some key variables following the collapse of $\delta_{\mathrm{EM}}$ calibrated so that Region EM's borrowing ability falls by 25 percent (see Panel 1). Panel 2 shows the output falls by 5 percent immediately after the shock. The reason behind this fall in output is the inability to channel domestic savings to investment opportunities, which is reflected in Panels 3 and 4. When savings in the EM region rise above and beyond the size of domestic corporate bonds, agents will increase their demand for local assets ${ }^{11}$ (due to home bias), thereby driving up the price of local assets (see Panel 5). Since the local asset supply has a limit (due to the lack of asset issuance in region EM), the excess savings is channeled to foreign investable assets (see Panel 6).

To recap, the calibration implies that an asset shortage leads to a slowdown in economic growth, an increase in local asset prices (potentially leading to a crisis if the asset shortage is excessive), and current account imbalances. Having calibrated the model, we will now econometrically estimate the relationship for our sample of EMs using macroeconomic data, and will confirm that asset shortages, as developed by Chen and Imam (2011), constrain economic growth, lead to domestic asset bubbles and ultimately a crisis, while also causing current account surpluses.

the relative supply of domestic corporate bond falls. Then domestic investor must buys local asset first, thereby pushing up the local asset price, and then foreign asset, creating capital outflow.

${ }^{11}$ For simplicity, we assume local assets have a linear supply curve; furthermore, there is a limit $\bar{L}$. Once this is passed, no more local assets can be issued. However, all the results are carried over to more complex models, as long as the supply of local assets does not fully meet the demand for assets from domestic investors. 
Figure 1. Reponses of the Key Variables After the Borrowing Ability Shock

1: Borrowing Ability in Region EM

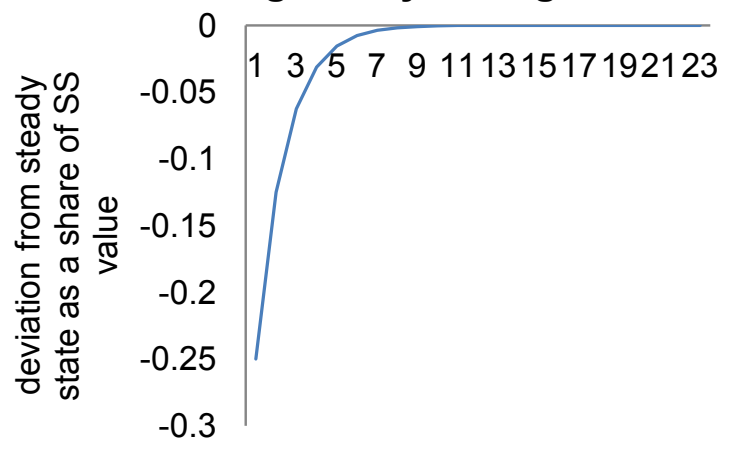

3: Asset Demand in Region EM

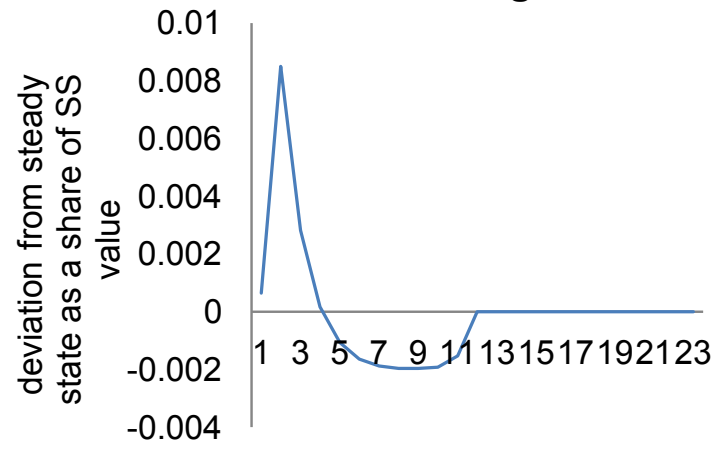

5: Local Asset Price

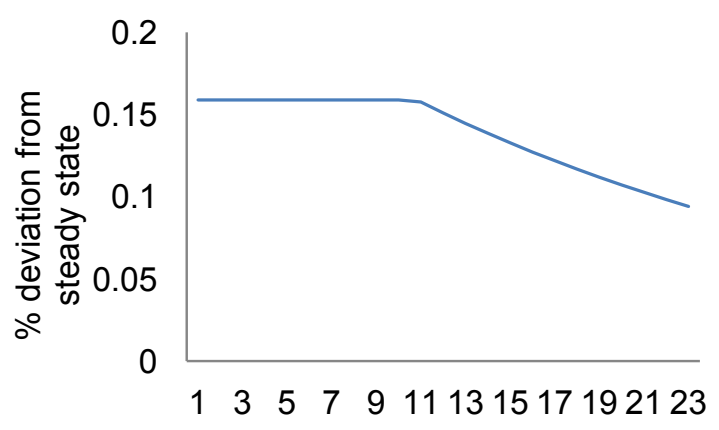

\section{2: Output in Region EM}

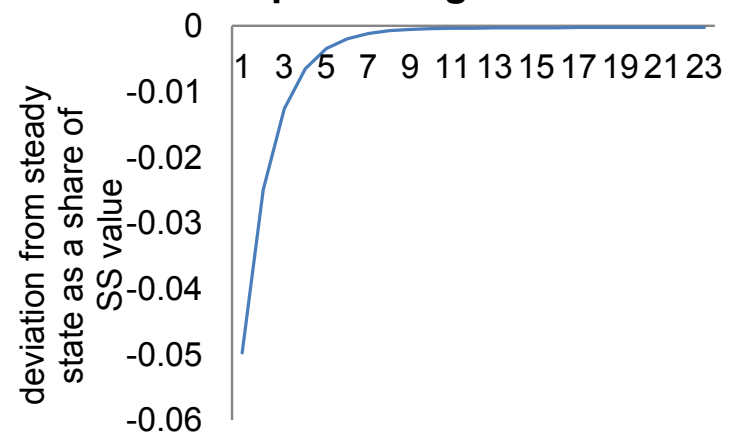

4: Asset Supply in Region EM

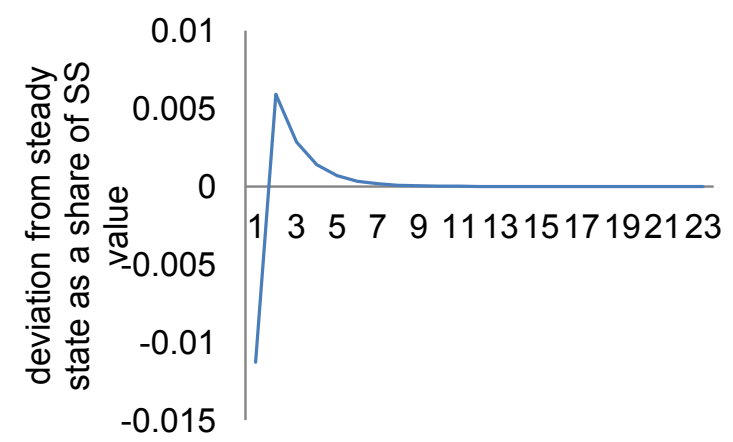

6: Current Account Balance in Region EM

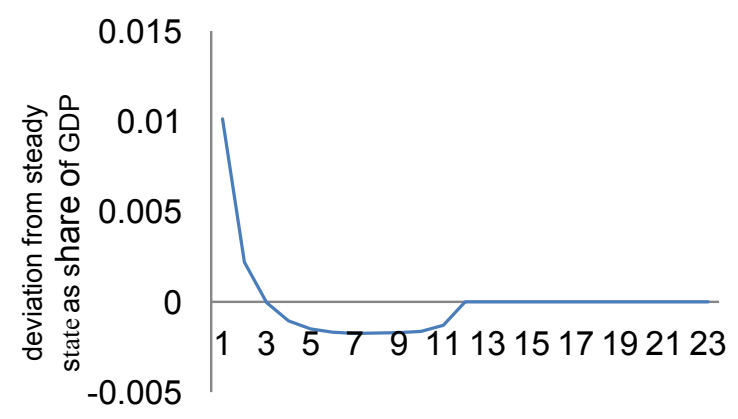




\section{Appendix 2. Country Classifications}

This table shows the list of countries are considered, divided into four groups following the classification used by the International Monetary Fund World Economic Outlook.

\begin{tabular}{ll}
\hline Latin America & East Asia \\
\hline Argentina & China, PR \\
Brazil & China, Hong Kong \\
Chile & India \\
Colombia & Indonesia \\
Mexico & Korea, Republic of \\
Panama & Malaysia \\
Peru & Philippines \\
Venezuela Rep. & Taiwan \\
& Thailand \\
& Vietnam \\
\hline \hline Middle East \& South Africa & \\
\hline Bahrain & East Europe \\
Egypt & Bulgaria \\
Israel & Croatia \\
Kazakhstan & Czech Republic \\
Kuwait & Hungary \\
Morocco & Latvia \\
Pakistan & Lithuania \\
Saudi Arabia & Poland \\
South Africa & Romania \\
Turkey & Russia Federation \\
UAE & Slovak Republic \\
& Slovenia \\
& Ukraine \\
\hline & \\
\hline
\end{tabular}




\section{Appendix 3. Correlation Matrix}

\begin{tabular}{|c|c|c|c|c|c|c|c|c|c|c|c|c|c|}
\hline Variable & $\begin{array}{c}\text { Asset } \\
\text { Shortage }\end{array}$ & GDP & Inflation & $\begin{array}{c}\text { Real Interest } \\
\text { Rate }\end{array}$ & $\begin{array}{c}\text { Country Credit } \\
\text { Rating }\end{array}$ & $\begin{array}{c}\text { Government } \\
\text { Deficit }\end{array}$ & $\begin{array}{c}\text { GDP per } \\
\text { Capita }\end{array}$ & $\begin{array}{c}\text { Current } \\
\text { Account }\end{array}$ & GDP Grow th & $\begin{array}{c}\text { Asset Bubble } \\
\text { Index }\end{array}$ & Total Trade & World GDP & $\begin{array}{l}\text { US Norminal } \\
\text { Interest Rate }\end{array}$ \\
\hline Asset Shortage Index & 1.000 & & & & & & & & & & & & \\
\hline GDP & 0.034 & 1.000 & & & & & & & & & & & \\
\hline Inflation & 0.035 & -0.057 & 1.000 & & & & & & & & & & \\
\hline Real Interest Rate & 0.168 & 0.018 & -0.285 & 1.000 & & & & & & & & & \\
\hline Country Credit Rating & -0.183 & -0.207 & -0.261 & -0.359 & 1.000 & & & & & & & & \\
\hline Government Deficit & -0.007 & -0.159 & -0.043 & -0.142 & 0.400 & 1.000 & & & & & & & \\
\hline GDP per Capita & -0.096 & -0.088 & -0.117 & -0.249 & 0.756 & 0.501 & 1.000 & & & & & & \\
\hline Current Account Balance & 0.010 & -0.075 & 0.006 & -0.130 & 0.224 & 0.614 & 0.302 & 1.000 & & & & & \\
\hline GDP Grow th & -0.113 & -0.027 & 0.255 & -0.532 & 0.109 & 0.168 & 0.051 & 0.086 & 1.000 & & & & \\
\hline Asset Bubble Index & 0.003 & -0.161 & -0.026 & 0.129 & 0.010 & 0.082 & 0.066 & 0.055 & -0.113 & 1.000 & & & \\
\hline Total Trade & -0.225 & -0.532 & 0.064 & -0.421 & 0.512 & 0.070 & 0.261 & 0.099 & 0.174 & 0.011 & 1.000 & & \\
\hline World GDP & -0.270 & 0.189 & 0.159 & -0.403 & 0.148 & 0.011 & 0.160 & -0.021 & 0.401 & 0.007 & 0.197 & 1.000 & \\
\hline US Norminal Interest Rate & 0.021 & 0.028 & -0.021 & 0.168 & -0.006 & 0.088 & 0.041 & -0.008 & -0.059 & -0.082 & -0.090 & -0.443 & 1.000 \\
\hline
\end{tabular}




\section{Appendix 4A. Econometric Methodology - System GMM}

The baseline regression of explaining the asset shortage index is the following:

$$
\Delta \cdot y_{i t}=\alpha \cdot y_{i, t-1}+\beta X_{i t}+\gamma Z_{i t}+v_{i}+\varepsilon_{i t}
$$

Where $y_{i t}$ is the dependent variable i.e., asset shortage index; $X_{i t}$ is the set of core explanatory variables; $Z_{i t}$ the set of additional explanatory variables.

The GMM (generalized method of moments) estimates the parameters by matching the population moments with the sample moments. In particular, dynamic panel GMM estimator can be described as follows.

Firstly, rewrite Equation (1) as $y_{i t}=(1+\alpha) \cdot y_{i, t-1}+\beta X_{i t}+\gamma Z_{i t}+v_{i}+\varepsilon_{i t}$. For simplicity, let us assume $Z_{i t}$ are included in $X_{i t}$. Now it can be written $y_{i t}=\lambda y_{i, t-1}+\beta X_{i t}+v_{i}+\varepsilon_{i t}, \mathrm{t}=1$, $2, \ldots, \mathrm{T}$. The fowling assumptions on the population moment are imposed:

Assumption 1 (error components): $E\left(v_{i}\right)=E\left(\varepsilon_{i t}\right)=E\left(v_{i} \varepsilon_{i t}\right)=0$

Assumption 2 (serially uncorrelated error term): $E\left(\varepsilon_{i s} \varepsilon_{i t}\right)=0$, for $t \neq s$

Assumption 3 (predetermined initial conditions): $E\left(y_{i 1} \varepsilon_{i t}\right)=E\left(X_{i 1} \varepsilon_{i t}\right)=0$, for $\mathrm{t}=2, \ldots, \mathrm{T}$

The DGMM (difference GMM) estimator uses the first-differencing transformation to eliminate the time-invariant country-fixed effects $v_{i}$.

For example: $y_{i 3}-y_{i 2}=\lambda\left(y_{i, 2}-y_{i 1}\right)+\beta\left(X_{i 2}-X_{i 1}\right)+\varepsilon_{i 3}-\varepsilon_{i 2}$ for $\mathrm{t}=3$.

Therefore, the lagged level $y_{i t}$ and $X_{i t}$ are valid IV (instrumental variables) for $\Delta y_{i 2}=\left(y_{i 2}-y_{i 1}\right)$ and $\Delta X_{i 2}=\left(X_{i 2}-X_{i 1}\right)$, respectively because they are uncorrelated with the error terms by assumption 3, i.e., $E\left(y_{i 1} \Delta \varepsilon_{i 3}\right)=E\left(X_{i 1} \Delta \varepsilon_{i 2}\right)=0$. Similarly, more moment conditions can be established from $E\left(y_{i t-2} \Delta \varepsilon_{i t}\right)$ and $E\left(X_{i t-2} \Delta \varepsilon_{i t}\right)=0, \forall t=3, \ldots, T ; s \geq 2$.

The SGMM (system GMM) estimator exploits additional moment's restrictions from first difference:

Assumption 4: $E\left(\Delta y_{i 2} v_{i}\right)=E\left(\Delta X_{i 2} v_{i}\right)=0$

Furthermore, assumption 4 implies the following moment conditions: $E\left(\Delta y_{i s}\left(v_{i}+\varepsilon_{i T}\right)=0\right.$ and $E\left(\Delta X_{i s}\left(v_{i}+\varepsilon_{i T}\right)\right)=0, \mathrm{~s}=2, \ldots, \mathrm{T}-1$. By incorporating the addition moment conditions, system GMM reduced finite sample bias compare to DGMM. (Bond (2002) and Roodman (2006)).

More specifically the equations that are estimated in this paper are: 
Appendix 4B. Econometric Methodology - Panel Unit Root Test (Im et al., 2003)

The test proposed by Im et al. (2003) is based on individual Augmented Dickey-Fuller (ADF) regressions:

$y_{i t}=\rho_{i} y_{i, t-1}+\sum_{j=1}^{p} \phi_{i t} \Delta y_{i, t-j}+z_{i, t} \gamma+\varepsilon_{i t}$

Where $y_{i t}$ stands for the variables to be tested, $\mathrm{p}$ is the number of lags for correlation-free residuals, $z_{i t}$ indicates the vector of determinist variables in the model including any fixed effects or individual trends and $\gamma$ is the corresponding vector of coefficients.

The null hypothesis is $\rho_{i}=0$ i.e., a unit root exist, against the alternative of no unit root ( $\rho_{i}<0$ for some $\mathrm{i}=1,2, \ldots, N_{1}$ and $\rho_{i}=0$ for $\mathrm{i}=N_{1}+1, \ldots, \mathrm{N}$, where $\mathrm{N}$ is the number of crosssections) is tested. Instead of pooling the data and assume the $\rho_{i}$ is the same for all countries (as in Levin et al. 2002), Im et al. (2003) use different unit root tests for the $\mathrm{N}$ countries. The test statistics based on the average of the adjusted Dickey-Fuller (ADF) test statistics calculated independently for each member of the panes and is defined as:

$\bar{t}=\frac{1}{N} \sum_{i=1}^{N}\left(t_{p i}\right)$

Where $t_{p i}$ is the individual t-statistic for testing the null hypothesis. The adjusted test statistic are distributed as $\mathrm{N}(0,1)$ under the null of a unit root, and large negative values lead to rejection of a unit root in favor of stationarity.

To carry out the unit root and cointegration tests, we select countries and time periods for each variable to construct a balanced panel, since we only considering two variables, no variables need to be eliminated. 


\section{Appendix 4C. Econometric Methodology - Panel Cointegration Test (Pedroni, 2004)}

In most general case, this may take the following form:

$$
y_{i t}=\alpha_{i}+\delta_{i} t+\beta_{i} X_{i t}+e_{i t} \quad i=1, \ldots, N ; t=1, \ldots, T
$$

Where $y_{i t}$ is the dependent variables, in this paper, is the GDP growth $X_{i t}$ is the independent variable corresponding to the asset shortage index. The parameters $\alpha_{i}$ and $\delta_{i}$ allow for the possibility of member specific fixed effect and deterministic trends, respectively. The slope coefficient $\beta_{i}$ is also permitted to vary by individual countries, allowing the heterogeneous across members of the panel in general cointegrating vectors. The variables $y_{i t}$ and $X_{i t}$ are assumed to be integrated of order one, denoted I(1), for each member $i$ of the panel under the null of no cointegreation the residual $e_{i t}$ will also be I(1).

In the paper the following test statistics based on estimated error $\hat{e}_{i t}$ have been considered,

$$
\begin{aligned}
& Z_{\hat{v} N T} \equiv \widehat{L}_{11}^{2}\left(\sum_{i=1}^{N} A_{22 i}\right)^{-1} \\
& Z_{\hat{\rho} N T^{-1}} \equiv\left(\sum_{i=1}^{N} A_{22 i}\right)^{-1} \sum_{i=1}^{N}\left(A_{21 i}-T \hat{\lambda}_{i}\right) \\
& Z_{\hat{\rho} N T^{-1}} \equiv\left(\tilde{\sigma}_{N T}^{2} \sum_{i=1}^{N} A_{22 i}\right)^{-1 / 2} \sum_{i=1}^{N}\left(A_{21 i}-T \hat{\lambda}_{i}\right) \\
& \tilde{Z}_{\hat{\rho} N T^{-1}} \equiv \sum_{i=1}^{N} A_{22 i}^{-1}\left(A_{21 i}-T \hat{\lambda}_{i}\right) \\
& \tilde{Z}_{\hat{t} N T} \equiv \sum_{i=1}^{N}\left(\hat{\sigma}_{i}^{2} A_{22 i}\right)^{-1 / 2}\left(A_{21 i}-T \hat{\lambda}_{i}\right)
\end{aligned}
$$

Under the null hypothesis that all of the individuals of the panel are not cointegrated, the tests statistics are shown to have a normal distribution under sequential limit.

More detailed discussion please see Pedroni (2004). 


\section{Appendix 4D. Econometric Methodology - Causality Tests for Cointegrated Panels (Pedroni, 2008)}

Pedroni (2008) developed a test, based on the dynamic error correction model proposed by Granger representation theorem (Engle and Granger, 1987). The estimation of the error correction from is carried out in two steps, firstly, estimate the co-integrating relationship between GDP growth and asset shortage index given in the previous equation, using either the Johansen $(1988,1991)$ maximum likelihood procedure or fully modified ordinary least squares. In the second step, using the estimated co-integrating relationship to construct the disequilibrium term, $\hat{e}_{i t}=g_{i t}-\hat{\alpha}_{i}-\hat{b}_{t}-\hat{\beta}_{i} y_{i t-j}$. Next, using the estimated error correction model, where g stands for the GDP growth and y is the asset shortage index.

$$
\begin{aligned}
& \Delta g_{i t}=c_{1 i}+\lambda_{1 i} \hat{e}_{i t-1}+\sum_{j=1}^{K} \varphi_{11 i j} \Delta g_{i t-j}+\sum_{j=1}^{K} \varphi_{12 i j} \Delta y_{i t-j}+\varepsilon_{1 i t} \\
& \Delta y_{i t}=c_{2 i}+\lambda_{2 i} \hat{e}_{i t-1}+\sum_{j=1}^{K} \varphi_{21 i j} \Delta g_{i t-j}+\sum_{j=1}^{K} \varphi_{22 i j} \Delta y_{i t-j}+\varepsilon_{2 i t}
\end{aligned}
$$

The variable $e_{i t}$ represents how far the variables from the equilibrium relationship and the error correction mechanism estimates how this disequilibrium cases the variables to adjust towards equilibrium in order to keep the long-run relationship intact. According to the Granger representation theorem at least one of the adjustment coefficients term $\lambda_{1 i}, \lambda_{2 i}$. Must be non-zero if a long-run relationship between the two variables holds.

By exploiting the co integrating relationship, the long-run effects of the innovations in the variables are summarized in $\lambda_{1 i}, \lambda_{2 i}$. 


\section{Appendix 5. Series Description and Data Sources}

This table shows the description of the data used and their sources. All variables are annual and at the country level.

\begin{tabular}{|c|c|c|}
\hline Series Name & Description & Source \\
\hline $\begin{array}{l}\text { Gross domestic product } \\
\text { (current US dollars) }\end{array}$ & $\begin{array}{l}\text { Gross domestic product at current price in US dollars. GDP data is converted from domestic currencies using yearly average } \\
\text { official exchange rates. }\end{array}$ & $\begin{array}{l}\text { IMF: World Economics Outlook; World } \\
\text { Bank: World Development Indicators }\end{array}$ \\
\hline $\begin{array}{l}\text { Gross domestic product per } \\
\text { capita (current US dollars) }\end{array}$ & GDP divided by total population. & $\begin{array}{l}\text { IMF: World Economics Outlook; World } \\
\text { Bank: World Development Indicators }\end{array}$ \\
\hline Gross Domestic Saving & $\begin{array}{l}\text { Defined as Gross National Disposable Income subtracts Total Expenditures. Data is converted from domestic currencies } \\
\text { using yearly average official exchange rates. }\end{array}$ & $\begin{array}{l}\text { IMF: International Financial Statistics, } \\
\text { World Economic Outlook; World Bank: } \\
\text { World Development Indicators }\end{array}$ \\
\hline $\begin{array}{l}\text { Bond Issuance in Domestic } \\
\text { (Foreign) Market }\end{array}$ & Data is converted from domestic currencies using yearly average official exchange & Dealogic \\
\hline $\begin{array}{l}\text { Loan Issuance in Domestic } \\
\text { (Foreign) Market }\end{array}$ & Data is converted from domestic currencies using yearly average official exchange & Dealogic \\
\hline $\begin{array}{l}\text { Equity Issuance in } \\
\text { Domestic (Foreign) Market }\end{array}$ & Data is converted from domestic currencies using yearly average official exchange & Dealogic \\
\hline Short Term Deposits & Data is converted from domestic currencies using yearly average official exchange & Bankscope \\
\hline $\begin{array}{l}\text { Net position of Foreign } \\
\text { holding of Domestic Assets }\end{array}$ & Foreigner's asset minus liabilities positions in domestic debt, equity, other investable assets and other investments. & IMF: Balance of Payments \\
\hline $\begin{array}{l}\text { Net position of Domestic } \\
\text { holding of Foreign Assets }\end{array}$ & Domestic investor's asset minus liabilities positions in foreign debt, equity, other investable assets and other investments. & IMF: Balance of Payments \\
\hline Real interest Rate & Nominal interest rate taken away inflation. & $\begin{array}{l}\text { World Bank: World Development } \\
\text { Indicators }\end{array}$ \\
\hline Inflation & $\begin{array}{l}\text { Inflation as measured by the log annual growth rate of the gross domestic product implicit deflator. We use the CPI if the } \\
\text { GDP-deflator is not available. }\end{array}$ & $\begin{array}{l}\text { IMF: World Economics Outlook; World } \\
\text { Bank: World Development Indicators }\end{array}$ \\
\hline Fiscal deficit & $\begin{array}{l}\text { The overall budget is total expenditure and lending minus repayments less current and capital revenue and official grant } \\
\text { received; shown as percentage of GDP. Data available for central government only }\end{array}$ & Haver Analytics \\
\hline Institutional Regulation & $\begin{array}{l}\text { Constructed from AREAER's provisions specific to institutional investors (including: Insurance companies, Pension funds, } \\
\text { Investment firms and collective, excluding banks). The restriction is on holding of both domestic and foreign assets. Due to } \\
\text { data availability and changing format of the report over the period we are interested, the outcome is a binary number, } 1= \\
\text { restriction exist, otherwise it is } 0 \text {. }\end{array}$ & $\begin{array}{l}\text { IMF: Annual Report on Exchange } \\
\text { Arrangements and Exchange } \\
\text { Restrictions (AREAER) }\end{array}$ \\
\hline World GDP & $\begin{array}{l}\text { The IMF revised the reporting format for capital account restrictions in 1996, when it started to provide more details on } \\
\text { aspects of capital account liberalization. Before 1996, the IMF measure of capital account liberalization is a simple dummy } \\
\text { variable. }\end{array}$ & $\begin{array}{l}\text { World Bank: World Development } \\
\text { Indicators }\end{array}$ \\
\hline $\begin{array}{l}\text { Degree of Capital account } \\
\text { openness (Kaopen) }\end{array}$ & $\begin{array}{l}\text { Constructed base on the four binary dummy variables: } 1 \text {, presence of multiple exchange rates; } 2 \text {, restrictions on current } \\
\text { account transactions; } 3 \text {, restrictions on capital account transactions and } 4 \text {, requirement of the surrender of export proceeds } \\
\text { reported in the IMF's Annual Report on Exchange Arrangements and Exchange Restrictions (AREAER). These variables are } \\
\text { to provide information on the extent and nature of the restrictions on external accounts. Higher the number means more } \\
\text { capital account openness. }\end{array}$ & Chinn, Ito (2005) \\
\hline de facto Exchange Rate & The number ranging from $1-6,1$ meaning de factor peg & Reinhart and Rogoff (2004) \\
\hline Real Exchange Rate & Number of foreign currency per 1 domestic currency & IMF: International Financial Statistics \\
\hline Institutionalized Democracy & $\begin{array}{l}\text { Democracy is conceived as three elements. } 1 \text {, the presence of institutions and procedures through which citizens can express } \\
\text { effective preference about alternative policies and leaders. } 2 \text {, the existence of institutionalized constraints on the exercise of } \\
\text { power by the executive. } 3 \text {, the guarantee of civil liberties to all citizens in their daily lives and in acts of political participations. }\end{array}$ & $\begin{array}{l}\text { Policy IV project - University of } \\
\text { Maryland }\end{array}$ \\
\hline
\end{tabular}

CInternational Monetary Fund. Not for Redistribution 


\begin{tabular}{|c|c|c|}
\hline Series Name & Description & Source \\
\hline & The indicator is an additive eleven-point scale $(0-10)$ & \\
\hline $\begin{array}{l}\text { Education Attainment } \\
\text { (Secondary) }\end{array}$ & Set of Panel data recording the education attainment in 146 countries from 1950 to 2010. & Barro, Lee 2010 \\
\hline $\begin{array}{l}\text { Trade Openness (Total } \\
\text { Trade) }\end{array}$ & Sum of imports and exports of goods and services over GDP & IMF: Balance of Payments \\
\hline Government Fiscal balance & & $\begin{array}{l}\text { IMF: Government Finance Statistics, } \\
\text { Staff Report; Haver Analytics, }\end{array}$ \\
\hline External Debt & & $\begin{array}{l}\text { IMF: International Financial Statistics; } \\
\text { Staff Report }\end{array}$ \\
\hline Government Debt & & $\begin{array}{l}\text { IMF: Government Finance Statistics, } \\
\text { Staff Report }\end{array}$ \\
\hline Government Revenue & & $\begin{array}{l}\text { IMF: Government Finance Statistics, } \\
\text { Staff Report }\end{array}$ \\
\hline Country Credit Rating & Short term Credit Rating for each country we are interested over 1990 - 2009 & Fitch \\
\hline Government Stability & $\begin{array}{l}\text { ICRG political risk sub-component (12\%) weight. This is a measure both of the government's ability to carry out its declared } \\
\text { program(s), and its ability to stay in office. This will depend on the type of governance, the cohesion of the government and } \\
\text { governing party or parties, the closeness of the next election, the government's command of the legislature, and popular } \\
\text { approval of government policies. }\end{array}$ & $\begin{array}{l}\text { Political Risk Services: International } \\
\text { Country Risk Guide. }\end{array}$ \\
\hline Crisis & 1 indicates the date of the crisis started; the dataset covers the universe of systemic banking crises for the period $1970-2007$. & Laeven and Valencia (2008) \\
\hline Economic risk rating & $\begin{array}{l}\text { The value of the Political Risk Service (PRS) Group's economic risk indicator (which ranges between } 0 \text { and } 50 \text { ). The risk } \\
\text { rating is a combination of } 5 \text { subcomponents: GDP levels and growth, respectively, inflation, balanced budgets, and the current } \\
\text { account. The minimum number of points for each component is zero, while the maximum number of points depends on the } \\
\text { fixed weight that component is given in the overall economic risk assessment. }\end{array}$ & $\begin{array}{l}\text { Political Risk Services: International } \\
\text { Country Risk Guide. }\end{array}$ \\
\hline Corruption & $\begin{array}{l}\text { ICRG political risk sub-component (6\%) weight. This is a measure of corruption within the political system. Such corruption: } \\
\text { distorts the economic and financial environment, reduces the efficiency of government and business by enabling people to } \\
\text { assume positions of power through patronage rather than ability, and introduces an inherent instability into the political } \\
\text { process. The most common form of corruption met directly by business is financial corruption in the form of demands for } \\
\text { special payments and bribes connected with import and export licenses, exchange controls, tax assessments, police } \\
\text { protection, or loans. Although the PRS measure takes such corruption into account, it is more concerned with actual or } \\
\text { potential corruption in the form of excessive patronage, nepotism, job reservations, "favor-for-favors," secret party funding, } \\
\text { and suspiciously close ties between politics and business. In PRS's view these sort of corruption pose risk to foreign } \\
\text { business, potentially leading to popular discontent, unrealistic and inefficient controls on the state economy, and encourage } \\
\text { the development of the black market. }\end{array}$ & $\begin{array}{l}\text { Political Risk Services: International } \\
\text { Country Risk Guide. }\end{array}$ \\
\hline Law and Order & $\begin{array}{l}\text { ICRG political risk sub-component (6\%) weight. PRS assess Law and Order separately, with each sub-component comprising } \\
\text { zero to three points. The Law sub-component is an assessment of the strength and impartiality of the legal system, while the } \\
\text { Order sub-component is an assessment of popular observance of the law. Thus, a country can enjoy a high rating (3.0) in } \\
\text { terms of its judicial system, but a low rating (1.0) if the law is ignored for a political aim. }\end{array}$ & $\begin{array}{l}\text { Political Risk Services: International } \\
\text { Country Risk Guide. }\end{array}$ \\
\hline $\begin{array}{l}\text { Risk for Exchange Rate } \\
\text { Stability }\end{array}$ & $\begin{array}{l}\text { Ranging from high \% change of either } 0.0-9.9 \text { appreciation or depreciation of } 0.1-4.9 \text { with risk points at } 10.0 \text {, to a midpoint of } \\
\text { either appreciation at } 50.0+\text { or depreciation of } 30.0-34.9 \text { with risk points at } 5.0 \text { to a low depreciation of } 100.0+\text { with } 0.0 \\
\text { points. The higher the points, the lower the risk. (Refer to ICRG Methodology for maximum points for this variable, as well as } \\
\text { for related formulas for calculating risk.) }\end{array}$ & $\begin{array}{l}\text { Political Risk Services: International } \\
\text { Country Risk Guide. }\end{array}$ \\
\hline Risk for Inflation & $\begin{array}{l}\text { Ranging from high \% of } 130+\text { with risk points at } 0.0 \text {, to a low of } 0.0 \text { with } 10.0 \text { points. The higher the points, the lower the risk. } \\
\text { (Refer to ICRG Methodology for maximum points for this variable, as well as for related formulas for calculating risk.) }\end{array}$ & $\begin{array}{l}\text { Political Risk Services: International } \\
\text { Country Risk Guide. }\end{array}$ \\
\hline Business Freedom & $\begin{array}{l}\text { Business Freedom is a quantitative measure of the ability to start, operate, and close a business that represents the overall } \\
\text { burden of regulation, as well as the efficiency of government in the regulatory process. The business freedom score for each } \\
\text { country is a number between } 0 \text { and } 100 \text {, with } 100 \text { equaling the freest business environment. The Score is based on } 10 \\
\text { factors, using data from the World Bank's Doing Business study. }\end{array}$ & The Heritage Foundation \\
\hline Financial Freedom & $\begin{array}{l}\text { Financial freedom is a measure of banking security as well as a measure of independence from government control. State } \\
\text { ownership of banks and other financial institutions is an inefficient burden that reduces competition and generally lowers the }\end{array}$ & The Heritage Foundation \\
\hline
\end{tabular}

(C)International Monetary Fund. Not for Redistribution 


\begin{tabular}{|c|c|c|}
\hline Series Name & Description & Source \\
\hline & level of available services. It has scale between 0 to 100,100 means negligible government influence. & \\
\hline Property Rights & $\begin{array}{l}\text { Property rights component is an assessment of the ability of individuals to accumulate private property, secured by clear laws } \\
\text { that are fully enforced by the state. It measures the degree to which a country's law protect private property rights and the } \\
\text { degree to which its government enforces those laws. It also assesses the likelihood that private property will be expropriated } \\
\text { and analyzes the independence of the judiciary, the existence of corruption within the judiciary, and the ability of individuals } \\
\text { and businesses to enforce contracts. It has scale between } 0 \text { and } 100,100 \text { means Private property is guaranteed by the } \\
\text { government, }\end{array}$ & The Heritage Foundation \\
\hline Local Sovereign Yield & & Haver Analytics \\
\hline External Sovereign Credit & & EMBIC Spread \\
\hline Price to Rent Ratio & & Global Property Indicator \\
\hline Price and Earning Ratio & & Bloomberg; IBES \\
\hline Commodity Prices Index & $\begin{array}{l}\text { The index is constructed using a set of weighted commodity prices, ranging from Petroleum, Natural gas; Copper, Aluminum } \\
\text { to Food prices }\end{array}$ & IMF Commodity Index \\
\hline
\end{tabular}

